Article

\title{
Clusters of Lactobacillus Strains from Vegetal Origins Are Associated with Beneficial Functions: Experimental Data and Statistical Interpretations
}

\author{
Nacim Barache ${ }^{1,2}$, Yanath Belguesmia ${ }^{2}$, Rabia Ladjouzi ${ }^{2}{ }^{\circ}$, Farida Bendali ${ }^{1, *(\mathbb{C})}$ and \\ Djamel Drider $2, *$ (D) \\ 1 Laboratoire de Microbiologie Appliquée, Faculté des Sciences de la Nature et de la Vie, Université de Bejaia, \\ Bejaia 06000, Algeria; nacimbarache@gmail.com \\ 2 BIOECOAGRO Unit of Research $\mathrm{N}^{\circ}$ 1158, Univ. Lille, INRAE, Univ. Liège, UPJV, YNCREA, Univ. Artois, \\ Univ. Littoral Côte d'Opale, ICV-Institut Charles Viollette, F-59000 Lille, France; \\ yanath.belgusmia@univ-lille.fr (Y.B.); Rabia.Ladjouzi@univ-lille.fr (R.L.) \\ * Correspondence: kamelea03@hotmail.com (F.B.); djamel.drider@univ-lille.fr (D.D.); \\ Tel.: +33-320-434-798 (D.D.)
}

Received: 27 June 2020; Accepted: 21 July 2020; Published: 24 July 2020

\begin{abstract}
Nine strains of Lactiplantibacillus plantarum and one strain of Lacticaseibacillus paracasei that were recently isolated from prickly pears, fresh figs and blackberries, which are traditionally and largely consumed fruits in Kabylia (north of Algeria), were studied here for their antagonism and antioxidant properties as well as for production of exopolysaccharides. With respect to their inhibitory properties, these strains were tested against three food representative pathogens including Escherichia coli ATCC 8739, Staphylococcus aureus 2S6 and Listeria monocytogenes 162. The antagonism of these pathogens was attributable to lactic acid production, present in the cell free supernatant, at concentrations ranging from 9 to $16.74 \mathrm{~g} / \mathrm{L}$. The anti-adhesive properties observed on polystyrene or eukaryotic Caco-2 cells were exerted in a strain dependent-manner. Indeed, the scores obtained ranged from $27 \%$ to $75 \%$ for S. aureus 2 S6, $54 \%$ to $95 \%$ for L. monocytogenes 162 , and $50 \%$ to $97 \%$ for E. coli ATCC 8739. The co-aggregation of these Lactobacillus strains with the aforementioned target bacteria appeared to be exerted in a strain-dependent manner, with noticeably the upmost rate for Lb. paracasei FB1 on S. aureus 2S6. Interestingly, these novel Lactobacillus strains were able to produce a large amount ( 315.55 to $483.22 \mathrm{mg} / \mathrm{L}$ ) of exopolysaccharides, and showed a significant scavenging activity on the 2,2-di-phényl-2-picrylhydrazyle (DPPH) synthetic free radical with rates of 51\% to $56 \%$. Of note, the highest antioxidant activity was observed for $L b$. paracasei FB1 using the culture supernatants, intact cells or the intracellular extract. The statistical analysis of these data using the principal component analysis (ACP) enabled us to establish three distinct clusters with potential applications as bioprotective and/or probiotic agents, following further evaluation.
\end{abstract}

Keywords: Lactobacillus; antagonism; lactic acid production; anti-adhesive properties; Caco-2 cells antioxidant activity; exopolysaccharides

\section{Introduction}

Foodborne pathogens represent a major health risk for consumers [1], causing a variety of foodborne diseases such as abdominal pain, diarrhea, fever, low blood pressure, vomiting and other gastrointestinal (GIT) symptoms [2,3]. Foodborne pathogens are considered as one of the most critical public health concerns spreading worldwide [4-6]. This unwanted spread of foodborne pathogens can negatively affect the whole economy. Indeed, according to the American Control Diseases Center (CDC) and FoodNet reports, bacterial pathogens such as Listeria monocytogenes, Escherichia coli, 
Staphylococcus aureus and Salmonella, associated with foodborne diseases, are responsible for huge economic casualties $[7,8]$. Antibiotics were then introduced and used for prophylaxis and treatment of bacterial GIT infections, with the aim to mitigate this imminent risk. However, their intensive use has enabled the emergence of human antibiotic resistant strains, which is a critical health challenge [9-11]. On the other hand, consumers are requesting more and more minimally processed foods with extended shelf-life, in which chemical additives are replaced by natural products endowed with safe and inhibitory activities [12,13]. Lactic acid bacteria (LAB) are natural and renewable sources offering various advantages including a hypocholestrolemic effect [14] and antioxidant activity [15], and can be used as preventive agents [16] or food bio-protective cultures [17]. Different studies pointed out the beneficial attributes of Lactobacillus strains, with emphasis on their capabilities to produce inhibitory molecules, or other molecules with benefits. With respect to food safety aspects, the Lactobacillus strains were steadily reported as natural means to inhibit foodborne pathogens, and alleviate oxidative damage in food system and human body, and further preventing related diseases [18-21].

Remarkably, probiotics, even at low concentrations, can inhibit the growth of intestinal pathogens through different mechanisms. They, indeed, can reduce their adhesion to intestinal epithelium, impact their capabilities to form biofilm, or impede their invasion process [22-24]. Lactobacillus can advantageously compete for resources available in the GIT [25]. For that scenario, LAB can deploy different strategies based on their abilities to produce organic acids, antimicrobial peptides such as bacteriocins, exopolysaccharides (EPS), or hydrogen peroxide [26,27]. Therefore, screening of new Lactobacillus strains endowed with such beneficial attributes is more than timely. Related to that, there is an increasing interest in unconventional sources such as traditional foods, which are steadily reported for their richness in Lactobacillus with probiotic and bio-preservative features [28-30].

The present and exhaustive study aimed at assessing and deciphering the antagonistic and antioxidant properties of Lactobacillus strains from prickly pears, fresh figs and blackberries, which are traditional fruits largely consumed in the north of Algeria.

\section{Materials and Methods}

\subsection{Microorganisms}

Lactobacillus strains used in this work were recently isolated from Algerian fruits [31]. They include Lb. plantarum M10 and M12 isolated from blackberries (Rubus sp.), Lb. plantarum F2, F3 and 2F8 isolated from fresh figs (Ficus carica); Lb. plantarum NCA3, NCA4, FB3, FB13 and Lb. paracasei FB1 isolated from prickly pears (Opuntia ficus-indica). Stocks of these strains were maintained at $-20^{\circ} \mathrm{C}$ in de Man Rogosa and Sharpe (MRS) broth (Conda, Madrid, Spain), containing 30\% (v/v) of glycerol (Sigma-Aldrich, Schnelldorf, Germany). These strains were cultivated anaerobically (AnaeroGen ${ }^{\mathrm{TM}} 2.5 \mathrm{~L}$, Anaerobic Gas Generator, Oxoid, Thermo, Hampshire, UK) for $18-24 \mathrm{~h}$ in MRS broth at $37^{\circ} \mathrm{C}$ prior use.

The target strains were E. coli ATCC 8739 isolated from feces, L. monocytogenes 162 isolated from food [32], and the clinical isolate S. aureus 2S6, kindly provided by Khalil Amrane hospital (Bejaia, Algeria). These strains were aerobically grown at $37^{\circ} \mathrm{C}$ in brain heart infusion (BHI) (Sigma-Aldrich) or in Luria-Bertani (LB) broth (Sigma-Aldrich) and stored at $-80^{\circ} \mathrm{C}$.

\subsection{Antibacterial Activity}

Taking into account that strains used here were not bacteriocinogenic, we focused our study on their capabilities to produce lactic acid. Thus, inhibitory properties of these ten Lactobacillus strains were assessed against E. coli ATCC 8739, S. aureus 2 S6 and L. monocytogenes 162 using both the well diffusion and the spot-on-lawn methods [33]. For the well method, $10 \mathrm{~mL}$ of BHI agar previously inoculated with the target strain at $10^{6} \mathrm{CFU} / \mathrm{mL}$ were added to the Petri plates. Once the medium became solid, wells were made and filled up with $50 \mu \mathrm{L}$ of neutralized or non-neutralized cell free supernatants (CFS), gathered from Lactobacillus cultures. Notably, CFS neutralization was performed with $3 \mathrm{M} \mathrm{NaOH}$, adjusting its external $\mathrm{pH}$ to 6.5 (pH 6.5). For the spot-on-lawn test, $5 \mu \mathrm{L}$ of Lactobacillus 
cultures were deposited on MRS plates, and incubated for $18 \mathrm{~h}$ at $37^{\circ} \mathrm{C}$. Afterwards, $10 \mathrm{~mL}$ of BHI agar (8 g agar/L) previously inoculated with the target strain, at $10^{6} \mathrm{CFU} / \mathrm{mL}$, were added and incubated again for $18 \mathrm{~h}$ at $37^{\circ} \mathrm{C}$. After incubation, the plates were inspected, any inhibition zone around the wells or the spots was recorded, and diameters were measured [33].

\subsection{Quantification of the Lactic Acid}

The quantification of lactic acid produced by Lactobacillus strains was performed by high performance liquid chromatography (HPLC) by spectra system P1000XR (Thermo Fisher Scientific, Waltham, MA, USA) using a Fast Fruit Juice Column $(50 \mathrm{~mm} \times 7.8 \mathrm{~mm}$, Phenomenex, Torrance, CA, USA). The mobile phase used was $\mathrm{H}_{3} \mathrm{PO}_{4}(0.05 \%, w / w)$, with a flow rate of $0.8 \mathrm{~mL} / \mathrm{min}$ and a temperature of $55^{\circ} \mathrm{C}$. Supernatants from Lactobacillus cultures were collected after 8, 18 and $24 \mathrm{~h}$ of incubation at $37^{\circ} \mathrm{C}$ in MRS broth, then centrifuged $\left(8000 \times \mathrm{g}, 10 \mathrm{~min}, 4{ }^{\circ} \mathrm{C}\right)$, and filtered through a filter of $0.2 \mu \mathrm{m} /$ pore size. The volume of injected sample was $25 \mu \mathrm{L}$, a calibration curve of pure lactic acid (Sigma-Aldrich) with concentrations of 1, 5, 10, 15 and $20 \mathrm{~g} / \mathrm{L}$ was carried out to establish the correlation between data obtained from chromatographic peaks area and produced lactic acid concentration. The peak corresponding to lactic acid, which is eluted at $5.32 \mathrm{~min}$ [34], was identified using the Azur software.

\subsection{Biofilm Formation Assessment of Lactobacillus Strains on Polystyrene Tissue Culture Plates (TCP)}

To assess the biofilm formation of the studied strains to polystyrene plate, a semi quantitative method was used, as previously described [35]. Briefly, $100 \mu \mathrm{L}$ of each culture of Lactobacillus $\left(10^{8} \mathrm{CFU} / \mathrm{mL}\right)$, grown in MRS broth, were added to the wells of sterile 96-well microplates already filled with $100 \mu \mathrm{L}$ of tryptic soy broth (TSB) (Difco, Detroit, MI, USA). The microplates were left for $15 \mathrm{~min}$ under gentle stirring before being incubated at $37^{\circ} \mathrm{C}$. After $24 \mathrm{~h}$, the cultures were aspirated and the non-adherent cells were removed by two washes of the wells with phosphate buffered saline (PBS, $10 \mathrm{mM}$, pH 7.2). Subsequently, $200 \mu \mathrm{L}$ of $96 \%$ ethanol (Sigma-Aldrich, St Louis, MO, USA) were added to each well in order to fix the adherent cells. After $15 \mathrm{~min}$ of fixation, the wells were drained, dried and then stained with $0.1 \%$ ( $w / v)$ crystal violet (Biochem Chemopharma, QC, Canada) for $30 \mathrm{~min}$. The stained cells were washed twice with $200 \mu \mathrm{L}$ of PBS before extracting the dye with $200 \mu \mathrm{L}$ of $96 \%$ ethanol. The number of cells was quantified using a microplate reader (ELX800, BioTek, Winooski, VT, USA) by measuring the absorbance (A) at $630 \mathrm{~nm}$. According to the recommendations of Stepanović et al. [36], these strains were classified into four categories. Considering Ac as the absorbance of the control (sterile TSB), the following interpretations were applied; $\mathrm{A} \leq \mathrm{Ac}$ : non-adherent (non-biofilm producer), 2Ac $\geq A>A c$ : weakly adherent (weak biofilm producer), $4 A c \geq A>2 A c$ : moderately adherent (moderate biofilm producer), and strongly adherent (strong biofilm producer): A $>4$ Ac.

\subsection{Exopolysaccharide Production}

The exopolysaccharide (EPS) production of Lactobacillus strains was evaluated according to the method described by van Geel-Schutten et al. [37]. Briefly, Lactobacillus strains were grown for $72 \mathrm{~h}$ at $37^{\circ} \mathrm{C}$ in $30 \mathrm{~mL}$ of MRS broth supplemented with $2 \%(w / v)$ glucose. Bacterial cells were removed by centrifugation $\left(6000 \times \mathrm{g}\right.$ for $\left.20 \mathrm{~min}, 20^{\circ} \mathrm{C}\right)$ and two volumes of $95 \%(v / v)$ cold ethanol (Sigma-Aldrich) were added to one volume of untreated CFS and maintained at $4{ }^{\circ} \mathrm{C}$ for $24 \mathrm{~h}$ to precipitate EPS. Then, the obtained precipitates were recovered by centrifugation $\left(2000 \times g, 15 \mathrm{~min}, 4{ }^{\circ} \mathrm{C}\right)$, washed with distilled water and dried at $60{ }^{\circ} \mathrm{C}$ until constant weight was reached. The dried weight was then measured to determine the amount of EPS produced by the Lactobacillus strains [29].

\subsection{Inhibition of Biofilm Formation by Lactobacillus CFS}

Firstly, $50 \mu \mathrm{L}$ of non-neutralized CFSs of Lactobacillus strains grown in MRS broth, and $50 \mu \mathrm{L}$ of E. coli ATCC 8739, S. aureus $2 \mathrm{~S} 6$ or L. monocytogenes 162 at $10^{6} \mathrm{CFU} / \mathrm{mL}$, prepared as above-indicated 
were mixed and added to the wells of sterile 96-well microplates containing $100 \mu \mathrm{L}$ of sterile TSB medium (Difco, Detroit, MI, USA). The microplates were left under gentle stirring for $15 \mathrm{~min}$ before their incubation for $24 \mathrm{~h}$ at $37^{\circ} \mathrm{C}$ [35]. Of note, the tests were performed in triplicate and sterile MRS broth was used as a negative control. According to Shokri et al. [38], to evaluate the pathogen biofilm removal by CFSs of lactobacilli, the aforementioned target strains were grown at $37^{\circ} \mathrm{C}$ for $24 \mathrm{~h}$ in the microplates wells, allowing them to form biofilms. Afterwards, $100 \mu \mathrm{L}$ of non-neutralized CFSs from Lactobacillus strain were added to the wells and then incubated again for $4 \mathrm{~h}$, at $37^{\circ} \mathrm{C}$. Each test was done in triplicate and sterile MRS broth $(100 \mu \mathrm{L})$ was used as a negative control. Biofilm reduction was measured using the same steps as for the biofilm quantification previously reported [35].

\subsection{Ultra-Structure Alterations as Visualized by Transmission Electron Microscopy (TEM)}

Cultures of E. coli ATCC 8739, S. aureus $2 \mathrm{~S} 6$ and L. monocytogenes 162 incubated at $37^{\circ} \mathrm{C}$ for $18 \mathrm{~h}$ were centrifuged $\left(8000 \times g, 10 \mathrm{~min}, 4^{\circ} \mathrm{C}\right)$, and the resulting cells were suspended in non-neutralized CFS of $\mathrm{Lb}$. plantarum $2 \mathrm{~F} 8$ cultures, which presented antibacterial and anti-adhesive activities as well as upmost lactic acid production. Sterile MRS broth ( $\mathrm{pH}$ 6.5) was used as a control. All suspensions were incubated for an additional $18 \mathrm{~h}$ at $37^{\circ} \mathrm{C}$. Samples were collected from each suspension and the cells were recovered by centrifugation $\left(8000 \times g, 10 \mathrm{~min}, 4^{\circ} \mathrm{C}\right)$ as a small pellet. For transmission electron microscopy (TEM), the pelleted cells were fixed with $2.5 \%(v / v)$ glutaraldehyde solution and $0.1 \mathrm{M}(v / v)$ of cacodylate buffer $(\mathrm{pH} 7.4)$ and prepared on a Formvar film of 300 square mesh, nickel grid (EMS FF300-Ni). The TEM images were recorded on a JEOL JEM 2100FX TEM instrument (Jeol, Tokyo, Japan) equipped with a GATAN CCD Orius 200D camera (Gatan, Pleasanton, CA, USA) at an acceleration voltage of $200 \mathrm{KV}$.

\subsection{Co-Aggregation Test}

The co-aggregation experiences were carried out as previously described by Kos et al. [39]. Briefly, the pathogenic strains E. coli ATCC 8739, S. aureus 2S6 and L. monocytogenes 162 as well as Lactobacillus strains were cultured at $37^{\circ} \mathrm{C}$ for $18 \mathrm{~h}$ in BHI and MRS broth, respectively. After centrifugation $(8000 \times g$, $\left.10 \mathrm{~min}, 4^{\circ} \mathrm{C}\right)$, the pelleted cells were washed twice with sterile PBS (10 mM, pH 7.2), and the cells were re-suspended in PBS to a final concentration of about $10^{8} \mathrm{CFU} / \mathrm{mL}$. Samples of $2 \mathrm{~mL}$ of Lactobacillus and pathogen suspensions were mixed by vortexing for $30 \mathrm{~s}$ in glass test tubes. Tubes containing $4 \mathrm{~mL}$ each pathogen suspension or Lactobacillus strain alone were considered as controls. Absorbance (A) was measured immediately and after $2 \mathrm{~h}$ of incubation at $37^{\circ} \mathrm{C}$. The following formula was used to calculate the co-aggregation percentage:

$$
\text { Co-aggregation }(\%)=[(\mathrm{Ax}+\mathrm{Ay}) / 2-\mathrm{A}(\mathrm{x}+\mathrm{y})] /[(\mathrm{Ax}+\mathrm{Ay}) / 2] \times 100
$$

where A represents the absorbance, $x$ and $y$ represent each strain in the control tubes, and $(x+y)$ represents their mixture.

\subsection{Inhibition of Pathogenic Strains Adhesion to Caco-2 Cells by Lactobacillus Strains}

The human colorectal adenocarcinoma Caco-2 cells were used for the adhesion inhibition assays [40]. The cells were grown at $37{ }^{\circ} \mathrm{C}$ in presence of $5 \% \mathrm{CO}_{2}$ in Dulbeco's modified Eagle medium (DMEM) containing $4.5 \mathrm{~g} / \mathrm{L}$ of glucose and supplemented with L-glutamine $(2 \mathrm{mM})$, penicillin $(100 \mathrm{U} / \mathrm{mL})$, streptomycin $(100 \mu \mathrm{g} / \mathrm{mL}), 10 \%$ of heat-inactivated fetal bovine serum (FBS) and 1\% $(v / v)$ non-essential amino acids. All these reagents were provided by PAN-Biotech $\mathrm{GmbH}$ (Aidenbach, Germany). The adhesion inhibition assays were carried out as described by Bendali et al. [41] including some adjustments. The 24-well tissue culture plates were used to prepare monolayers of Caco- 2 cells. The wells were inoculated by $4.10^{4} \mathrm{Caco}-2$ cells per well, and the plates were incubated for 7 days. Two different protocols were used in order to discriminate competition/exclusion of E. coli ATCC 8739, S. aureus 2 S6 and L. monocytogenes 162 with/by lactobacilli. 
For exclusion tests, Lactobacillus strains at $10^{8} \mathrm{CFU} / \mathrm{mL}$, washed with $1 \mathrm{~mL}$ of $\mathrm{PBS}$ and resuspended in DMEM without serum or antibiotics, were added to Caco-2 cell monolayers and incubated for $90 \mathrm{~min}$ at $37^{\circ} \mathrm{C}\left(5 \% \mathrm{CO}_{2}\right)$. Afterwards, non-adherent Lactobacillus strains were removed by washing twice with PBS, and E. coli ATCC 8739, S. aureus $2 \mathrm{S6}$ or L. monocytogenes 162 at $10^{7} \mathrm{CFU} / \mathrm{mL}$, prepared in the same conditions as Lactobacillus strains, were added and incubated for an additional $2 \mathrm{~h}$ at $37^{\circ} \mathrm{C}$. Here, bacterial charges were added to Caco- 2 cells monolayer taking into account the multiplicity of infection (MOI) ratio, in agreement with a previously report [42]. Of note, the MOI ratio of lactobacilli was 1:100 (Caco2: lactobacilli), while that for pathogens was 1:10 (Caco2: pathogens).

For competition tests, Lactobacillus $\left(10^{8} \mathrm{CFU} / \mathrm{mL}\right)$ and pathogen $\left(10^{7} \mathrm{CFU} / \mathrm{mL}\right)$ strains, both prepared as previously described, were mixed and added to the Caco-2 monolayers and incubated for $2 \mathrm{~h}$ at $37^{\circ} \mathrm{C}$. Then, the Caco-2 monolayers were washed twice with $500 \mu \mathrm{L}$ of PBS and incubated with $200 \mu \mathrm{L}$ of Trypsin/EDTA (Gibco) for $15 \mathrm{~min}$ to remove Caco-2 cells with adherent bacteria.

After exclusion and competition tests, the enumeration of adherent E. coli ATCC 8739, S. aureus 2 S6 and L. monocytogenes 162 cells was performed on specific media for each strain; eosine methylene blue (EMB), Chapman Stone agar and Palcam agar, respectively. Pathogen adhesion rates were calculated in reference to the control (well containing pathogens without Lactobacillus strains) which represents $100 \%$ adhesion.

\subsection{CFS, Intact Cells and Intracellular Cell-Free Extract Scavenging Activity on Free Radical DPPH}

Lactobacillus strains cultures were inoculated into MRS broth and incubated at $30^{\circ} \mathrm{C}$ for $18 \mathrm{~h}$ and the overnight culture was centrifuged $\left(8000 \times \mathrm{g}\right.$ at $4{ }^{\circ} \mathrm{C}$ for $\left.10 \mathrm{~min}\right)$. The cell-free supernatants were subjected to 2,2-di-phényl-2-picrylhydrazyle (DPPH) free radical scavenging assay, as described by Sharma et al. [43]. A volume of $500 \mu \mathrm{L}$ of cell-free supernatants was added to $3 \mathrm{~mL}$ of freshly prepared DPPH ( $5 \mathrm{mg} / 100 \mathrm{~mL}$ of methanol), mixed by vortexing and incubated for $30 \mathrm{~min}$ in the dark. After $30 \mathrm{~min}$, absorbance was measured at $515 \mathrm{~nm}$ with non-inoculated MRS broth as blank. Ascorbic acid was used as the synthetic and natural standard. The percentage of radical scavenging activity was calculated according to the equation:

$$
\text { Scavenging }(\%)=[1-\mathrm{A} 515(\text { sample) }) / \text { A515 (blank) }] \text { 100\% }
$$

Cells of lactobacilli were harvested by centrifugation $\left(8000 \times \mathrm{g}\right.$ at $4{ }^{\circ} \mathrm{C}$ for $10 \mathrm{~min}$ ) after $18 \mathrm{~h}$ of incubation at $30^{\circ} \mathrm{C}$. For the preparation of intact cells, cells were washed three times with PBS $(10 \mathrm{mM}$, $\mathrm{pH}$ 7.2) and resuspended at $10^{9} \log \mathrm{CFU} / \mathrm{mL}$ in this same buffer. To prepare intracellular cell-free extracts, cell pellets were quickly washed twice with deionized water and resuspended in the same solution before transferring to NucleoSpin ${ }^{\circledR}$ Bead Tubes Type B (Macherey-Nagel, Duren, Germany). Tubes were homogenized using FastPrep-24 5G (MP Biomedicals, Santa Ana, CA, USA) for 3 cycles of $30 \mathrm{~s}$, with cooling on ice bath for $5 \mathrm{~min}$ between each cycle. Cell debris was removed by centrifugation at $11,000 \times \mathrm{g}$ at $4{ }^{\circ} \mathrm{C}$ for $10 \mathrm{~min}$, allowing the recovery of a supernatant containing intracellular cell-free extract $[44,45]$. As previously described by Lin and Chang, with slight modification, $800 \mu \mathrm{L}$ of a milliliter of intact cells or intracellular cell-free extract were mixed with $1 \mathrm{~mL}$ of freshly prepared DPPH solution $(0.004 \%, w / v$ in methanol) and the scavenging ability was calculated as stated above using PBS as a blank.

\subsection{Statistical Analysis}

Differences between samples were calculated using one way ANOVA and the post hoc Tukey test $(p<0.05)$ XL-STAT (version 2009, Addinsoft, Paris, France), and data were expressed as a mean \pm standard error calculated from at least three independent experiments. The resulting data were analyzed by principal component analysis (PCA) using FactoMineR software. The principal component analysis was performed using version R 3.5.2 (www.r-project.org, $\mathrm{R}$ foundation for statistical computing). 


\section{Results}

\subsection{Lactobacillus Strains Displayed Antibacterial Properties through Different Mechanisms}

The ten Lactobacillus strains inhibited noteworthy results regarding the growth of the three pathogenic strains used here, according to the results from the spot-on-lawn method (Table 1). Nevertheless, this antagonism was attributed to the non-neutralized CFS based on the well diffusion method. Furthermore, the diameters of the inhibition zones obtained for all Lactobacillus strains were similar, regardless of the considered pathogen, except for Lb. paracasei FB1 strain, which exhibited lower inhibition zone diameters (Table 1).

Table 1. Inhibition of pathogenic bacteria by Lactobacillus strains based on two different methods.

\begin{tabular}{|c|c|c|c|c|c|c|c|}
\hline \multirow{2}{*}{ Strain } & \multicolumn{6}{|c|}{ Diameter of Inhibition Zones Given in Millimeters (mm) } & \multirow{2}{*}{$\begin{array}{c}\text { Supernatants } \\
\text { pH }\end{array}$} \\
\hline & $\begin{array}{c}\text { E. coli } \\
\text { ATCC } 8739\end{array}$ & $\begin{array}{l}\text { S. aureus } \\
2 S 6\end{array}$ & $\begin{array}{c}\text { L. monocytogenes } \\
162\end{array}$ & $\begin{array}{c}\text { E. coli } \\
\text { ATCC } 8739\end{array}$ & $\begin{array}{l}\text { S. aureus } \\
2 \mathrm{~S} 6\end{array}$ & $\begin{array}{c}\text { L. monocytogenes } \\
162\end{array}$ & \\
\hline M10 & $43 \pm 1.00^{\mathrm{a}}$ & $31 \pm 1.04^{\mathrm{a}, \mathrm{b}}$ & $21 \pm 1.04^{\mathrm{d}}$ & $14 \pm 0.29^{a}$ & $13 \pm 1.00^{\mathrm{a}}$ & $13 \pm 0.35^{\mathrm{a}}$ & $3.81 \pm 0.00^{\mathrm{c}, \mathrm{d}}$ \\
\hline M12 & $41 \pm 1.52^{\mathrm{a}}$ & $31 \pm 1.00^{\mathrm{a}, \mathrm{b}}$ & $23 \pm 1.04^{b, c, d}$ & $13 \pm 0.35^{\mathrm{a}, \mathrm{b}}$ & $13 \pm 0.50^{\mathrm{a}}$ & $13 \pm 0.16^{\mathrm{a}}$ & $3.79 \pm 0.02^{c, d}$ \\
\hline $2 \mathrm{~F} 8$ & $42 \pm 1.72^{a}$ & $31 \pm 1.30^{a, b}$ & $27 \pm 0.50^{a}$ & $14 \pm 0.80^{\mathrm{a}}$ & $13 \pm 0.23^{\mathrm{a}}$ & $12 \pm 0.35^{\mathrm{a}, \mathrm{b}}$ & $3.79 \pm 0.02^{c, d}$ \\
\hline NCA3 & $37 \pm 1.50^{b, c}$ & $30 \pm 1.00^{\mathrm{a}, \mathrm{b}}$ & $23 \pm 1.52^{b, c, d}$ & $12 \pm 0.60^{b}$ & $10 \pm 0.57^{c}$ & $11 \pm 0.29^{b}$ & $3.94 \pm 0.01^{b}$ \\
\hline NCA4 & $36 \pm 1.00^{c, d}$ & $29 \pm 1.23^{a, b}$ & $22 \pm 1.15^{b, c, d}$ & $12 \pm 1.00^{b}$ & $10 \pm 0.57^{c}$ & $11 \pm 0.29^{b}$ & $3.98 \pm 0.02^{b}$ \\
\hline FB1 & $25 \pm 2.00^{\mathrm{e}}$ & $23 \pm 0.20^{c}$ & $23 \pm 0.50^{b, c, d}$ & $12 \pm 0.30^{b}$ & $11 \pm 0.46^{b, c}$ & $11 \pm 0.17^{b}$ & $4.07 \pm 0.01^{a}$ \\
\hline FB3 & $32 \pm 1.60^{d}$ & $31 \pm 0.91^{\mathrm{a}}$ & $22 \pm 0.50^{c, d}$ & $12 \pm 1.00^{b}$ & $11 \pm 0.29 b, c$ & $11 \pm 0.50^{b}$ & $4.10 \pm 0.00^{a}$ \\
\hline FB13 & $37 \pm 1.80^{b, c}$ & $31 \pm 1.00^{a, b}$ & $22 \pm 1.50^{\mathrm{c}, \mathrm{d}}$ & $13 \pm 0.65^{a, b}$ & $12 \pm 0.35^{\mathrm{a}, \mathrm{b}}$ & $12 \pm 1.00^{a, b}$ & $3.78 \pm 0.01^{d}$ \\
\hline
\end{tabular}

Results are expressed as mean \pm standard deviation $n=3$, means with different lowercase letters were significantly different $(p<0.05)$ based on Tukey's test.

\subsection{Lactic Acid Quantification}

The absence of inhibition when the neutralized CFS was used indicated that antibacterial activity was due to the $\mathrm{pH}$ lowering, most likely due to the production of lactic acid. Related to that, we noticed that $L b$. plantarum F3 and 2F8 strains produced the greatest amounts of lactic acid, reaching $16.74 \mathrm{~g} / \mathrm{L}$ after $24 \mathrm{~h}$ of growth. However, the lowest production was registered for Lb. paracasei FB1 and Lb. plantarum FB3 with 10.73 and 9.64 g/L, respectively (Table 2).

Table 2. Lactic acid and exopolysaccharides (EPS) production in Lactobacillus strains.

\begin{tabular}{ccccc}
\hline \multirow{2}{*}{ Strain } & \multicolumn{3}{c}{ Lactic Acid Quantification $\mathbf{( g / L )}$} & \multirow{2}{*}{ EPS Production (mg/L) } \\
\cline { 2 - 4 } & $\mathbf{8} \mathbf{h}$ & $\mathbf{1 8} \mathbf{h}$ & $\mathbf{2 4} \mathbf{h}$ & \\
\hline M10 & $4.18 \pm 0.06^{\mathrm{b}}$ & $12.4 \pm 0.64^{\mathrm{a}, \mathrm{b}}$ & $15.28 \pm 0.13^{\mathrm{b}}$ & $424.48 \pm 23.59^{\mathrm{b}, \mathrm{c}}$ \\
M12 & $3.76 \pm 0.06^{\mathrm{c}}$ & $13.20 \pm 0.28^{\mathrm{a}}$ & $16.15 \pm 0.18^{\mathrm{a}, \mathrm{b}}$ & $436.47 \pm 14.82^{\mathrm{a}, \mathrm{b}, \mathrm{c}}$ \\
F2 & $4.27 \pm 0.06^{\mathrm{b}}$ & $11.05 \pm 1.03^{\mathrm{b}, \mathrm{c}}$ & $15.88 \pm 0.22^{\mathrm{a}, \mathrm{b}}$ & $454.12 \pm 25.53^{\mathrm{a}, \mathrm{b}}$ \\
F3 & $4.86 \pm 0.04^{\mathrm{a}}$ & $12.55 \pm 0.43^{\mathrm{a}}$ & $16.74 \pm 0.36^{\mathrm{a}}$ & $453.32 \pm 17.55^{\mathrm{a}, \mathrm{b}}$ \\
2F8 & $4.58 \pm 0.07^{\mathrm{a}}$ & $12.84 \pm 0.14^{\mathrm{a}}$ & $16.74 \pm 0.30^{\mathrm{a}}$ & $425.13 \pm 11.81^{\mathrm{b}, \mathrm{c}}$ \\
NCA3 & $4.17 \pm 0.24^{\mathrm{b}}$ & $12.85 \pm 0.26^{\mathrm{a}}$ & $15.19 \pm 0.24^{\mathrm{a}, \mathrm{b}}$ & $433.18 \pm 14.57^{\mathrm{b}, \mathrm{c}}$ \\
NCA4 & $4.77 \pm 0.02^{\mathrm{a}}$ & $13.65 \pm 0.13^{\mathrm{a}}$ & $16.21 \pm 0.62^{\mathrm{a}, \mathrm{b}}$ & $483.22 \pm 15.39^{\mathrm{a}}$ \\
FB1 & $3.01 \pm 0.09^{\mathrm{e}}$ & $9.88 \pm 0.36^{\mathrm{c}}$ & $10.73 \pm 0.37^{\mathrm{c}}$ & $315.55 \pm 13.87^{\mathrm{d}}$ \\
FB3 & $2.59 \pm 0.13^{\mathrm{f}}$ & $7.18 \pm 0.36^{\mathrm{d}}$ & $9.64 \pm 0.33^{\mathrm{d}}$ & $402.22 \pm 18.76^{\mathrm{c}}$ \\
FB13 & $3.40 \pm 0.07^{\mathrm{d}}$ & $12.57 \pm 0.25^{\mathrm{a}}$ & $15.67 \pm 0.35^{\mathrm{b}}$ & $412.69 \pm 10.69^{\mathrm{b}, \mathrm{c}}$
\end{tabular}

Results are expressed as mean \pm standard deviation $n=3$, means with different lowercase letters were significantly different $(p<0.05)$ based on Tukey's test.

\subsection{Adhesive Capacity of Lactobacillus and Pathogenic Strains on Polystyrene Microplates}

The results illustrated in Figure 1 highlight the capabilities of Lactobacillus strains to adhere and form biofilms under the tested conditions. Consequently, the absorbencies recorded for Lactobacillus 
strains ranged from 0.26 to 1.78 (Figure 1). Nine out 10 strains were strongly adherent according to the classification proposed by Stepanović et al. [36], whereas Lb. plantarum FB3 appeared to be moderately adherent. Remarkably, the most adherent strains were Lb. plantarum FB13 followed by Lb. plantarum NCA4. Regarding the pathogenic strains, the absorbencies recorded for E. coli ATCC 8739, L. monocytogenes 162 and S. aureus 2 S6 were $0.366,0.422$ and 1.368 , respectively. Therefore, S. aureus 2 S6 was thereof considered as strongly adherent, while E. coli ATCC 8739 and L. monocytogenes 162 were moderately adherent.

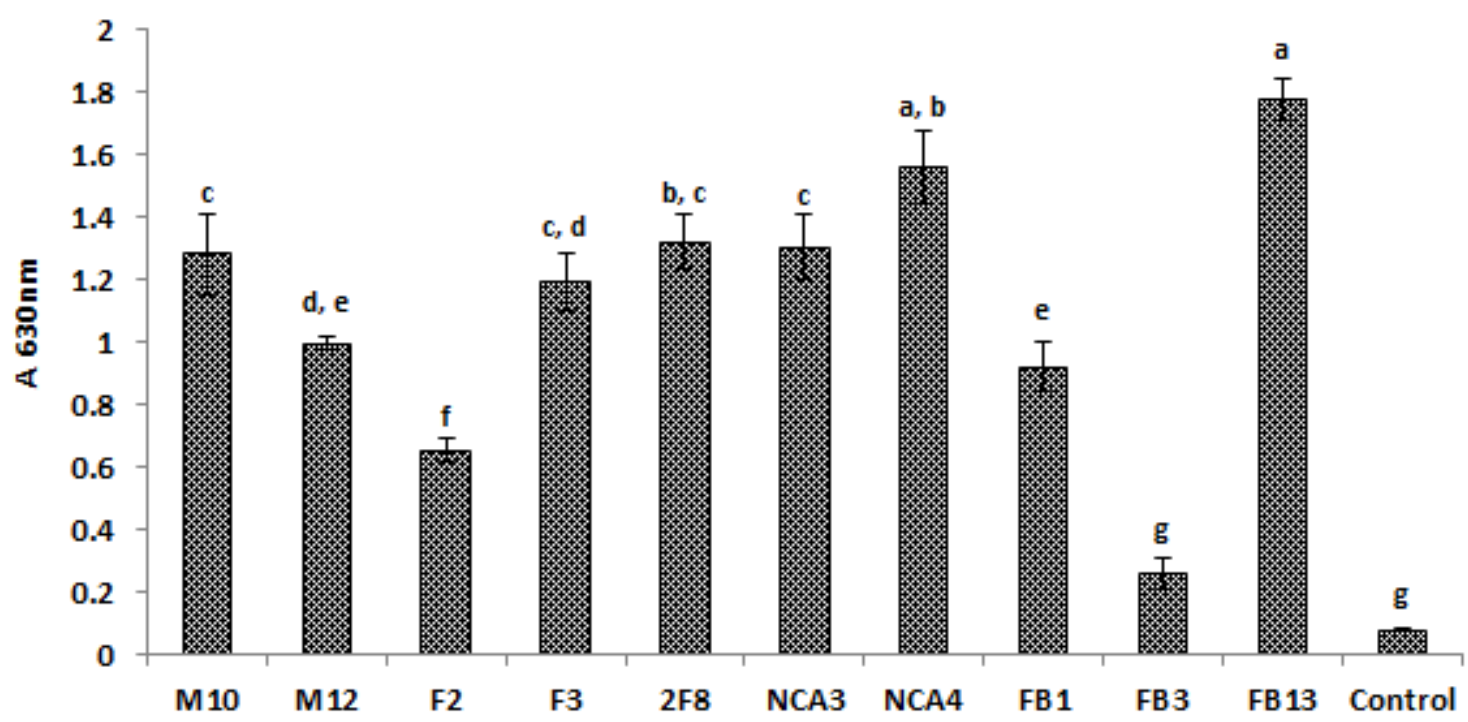

Figure 1. Adhesion of Lactobacillus strains to polystyrene plates as determined by $\mathrm{A}_{630 \mathrm{~nm}}$ measurements. The absorbance values are the means of three independent experiments. Sterile tryptic soy broth (TSB) was used as a control. The error bars represent the standard deviations. Columns without common letter are significantly different $(p<0.05)$ using Tukey's test.

\subsection{The CFS from Lactobacillus Strains Were Able to Prevent the Pathogens Biofilm Formation}

The non-neutralized CFS from all tested Lactobacillus strains were able to prevent the adhesion and subsequently the biofilm formation of E. coli ATCC 8739, S. aureus 2 S6 and L. monocytogenes 162 based on the data obtained with the semi quantitative TCP method (Figure 2A). The adhesion inhibition rates ranged between $77.23 \% \pm 1.02 \%$ and $89.40 \% \pm 0.41 \%$. The significantly most important percentage of inhibition was registered for $\mathrm{Lb}$. plantarum FB3 $(89.40 \% \pm 0.41 \%)$ against $\mathrm{S}$. aureus $2 \mathrm{~S} 6$ biofilm formation. In addition, these Lactobacillus strains were able to remove the formed biofilms after $4 \mathrm{~h}$ of contact with the non-neutralized CFS (Figure 2B). Therefore, the biofilm removal levels ranged from $52.60 \% \pm 0.42 \%$ to $78.02 \% \pm 1.91 \%$, and the significantly highest rate of removal was shown for Lb. paracasei FB1 against L. monocytogenes 162 biofilm. 


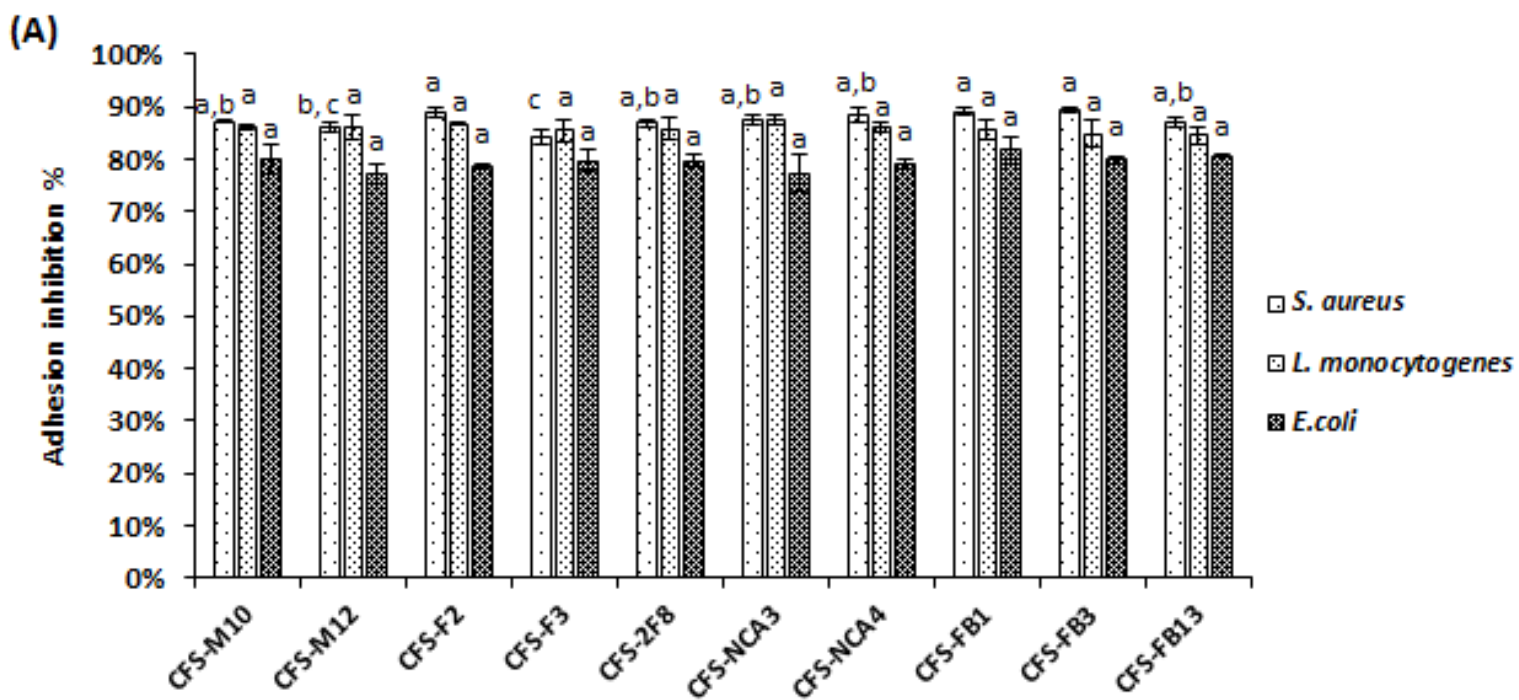

(B)

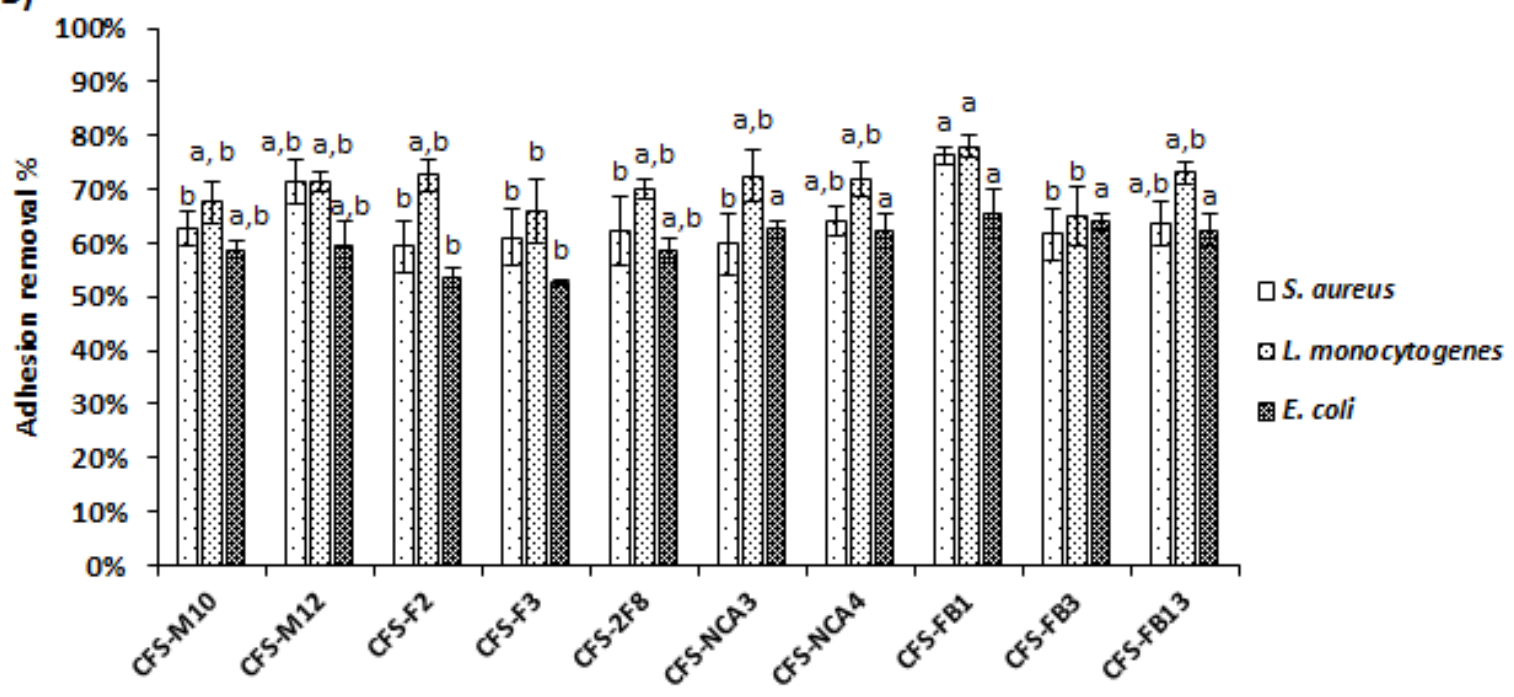

Figure 2. Adhesion inhibition (A) and removal (B) rates of pathogens (S. aureus 2S6, E. coli ATCC 8739 and L. monocytogenes 162) on polystyrene microplates, by Lactobacillus non-neutralized cell-free supernatants. The positive control was the non-treated pathogens suspensions, and the negative control was the pathogens suspensions treated with sterile de Man Rogosa and Sharpe (MRS) broth. The rates are the means of three independent experiments. The error bars represent the standard deviations. Columns without common letter are significantly different $(p<0.05)$ using Tukey's test.

\subsection{Exopolysaccharide Production}

Lactobacilli strains were found to be able to produce 315.55 to $483.22 \mathrm{mg} / \mathrm{L}$ of EPS (Table 2). Furthermore, production of EPS in significantly $(p<0.05)$ higher amounts was displayed by Lb. plantarum NCA4 (483.22 mg/L), followed by Lb. plantarum F2 $(454.12 \mathrm{mg} / \mathrm{L})$ and F3 $(453.32 \mathrm{mg} / \mathrm{L})$. On the other hand, Lb. paracasei FB1 was found to be the lowest EPS producer, with only $315.55 \mathrm{mg} / \mathrm{L}$.

\subsection{Cellular Ultra-Structural Alterations of Pathogens Treated with CFS Examined by Transmission Electron Microscopy (TEM)}

TEM was used to observe the ultra-structural modifications, if any, of pathogens cells treated with CFS from Lactobacillus strains. The data gathered showed the disruption of the cell wall structure and the condensation of ribosomes. Therefore, bacterial death resulted from the wall's mechanical strength and osmotic lysis. The cytoplasm content of treated E. coli cells was agglutinated and appeared as 
globules of variable size. Nevertheless, the membrane was easily observed as being devoid of any break or clear cut (Figure 3A(2)). Notably, the treated S. aureus cells did not show any particular intracellular damage. The cell wall was altered with a "frayed" appearance, indicating a possible peptidoglycan alteration (Figure 3B(2)). Regarding L. monocytogenes, cells exhibited an altered cell wall, separation of membrane layers and leakage of intracellular contents (Figure $3 \mathrm{C}(2)$ ).
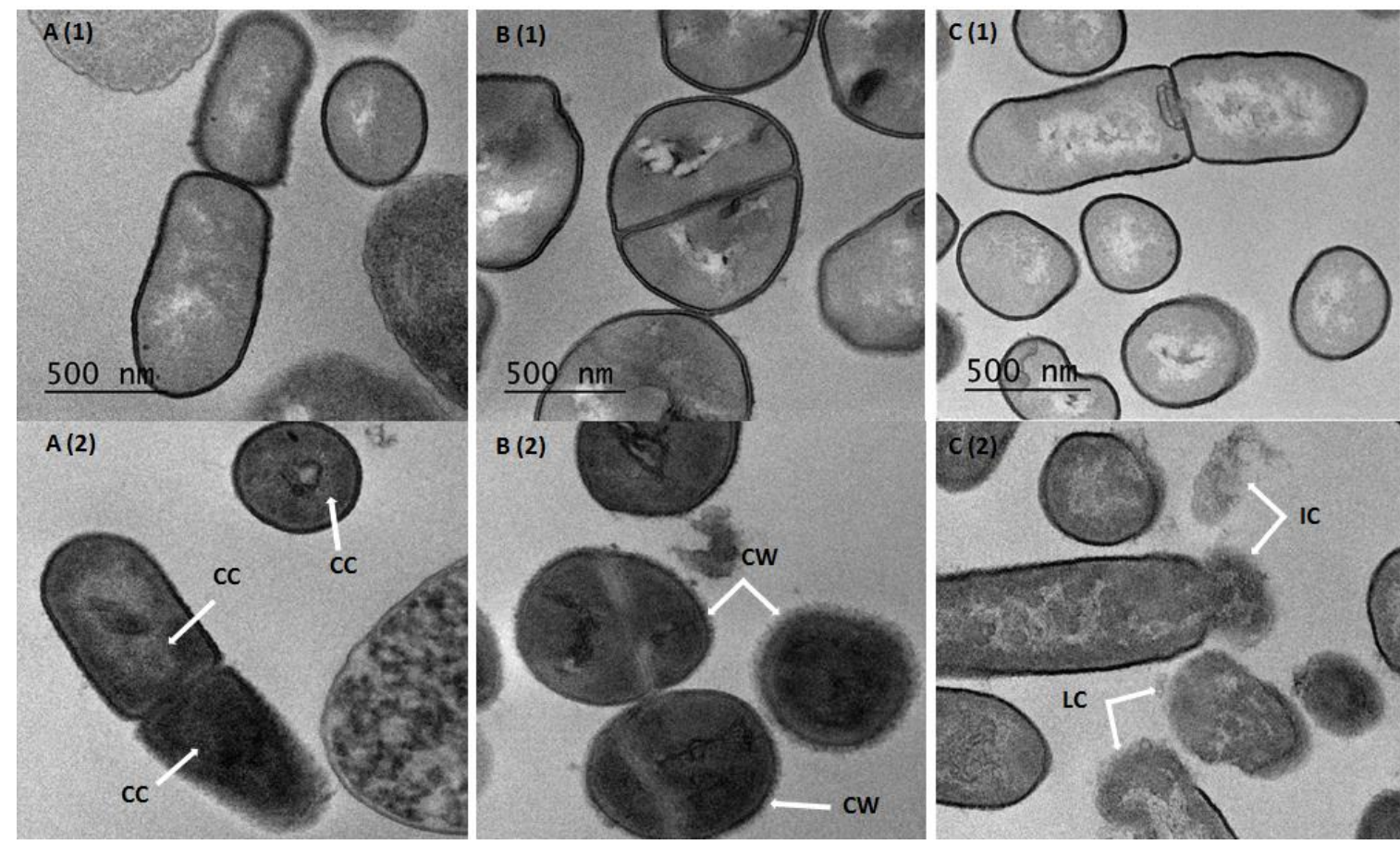

Figure 3. Transmission electron micrographs of non-treated E. coli ATCC 8739 (A(1)), S. aureus 2S6 (B(1)) and L. monocytogenes $162(\mathrm{C}(1))$ cells, and treated cells with non-neutralized CFS of Lb. plantarum 2F8: E. coli ATCC $8739(\mathbf{A}(2))$, S. aureus 2S6 (B(2)) and L. monocytogenes $162(\mathbf{C}(2))$. The arrows indicate the main alterations. Abbreviations: cytoplasm contents (CC), cell wall (CW), intracellular contents (IC) and lysed cells (LC).

\subsection{The Co-Aggregation Ability of Lactobacilli with Pathogens}

The co-aggregation of the ten-studied Lactobacillus strains with the three pathogens (E. coli ATCC 8739 , S. aureus $2 \mathrm{~S} 6$ and L. monocytogenes 162 ) is shown in Figure 4 . Notably, the co-aggregation registered for $L b$. paracasei FB1 after $2 \mathrm{~h}$ of incubation was significantly $(p<0.05)$ stronger with $S$. aureus $(28.34 \% \pm 2.56 \%)$, followed by those obtained for E. coli $(23.39 \% \pm 2.12 \%)$, and L. monocytogenes $(20.10 \% \pm 2.04 \%)$. Interestingly, Lb. plantarum NCA4 showed co-aggregation with L. monocytogenes but not with E. coli ATCC 8739 and S. aureus 2S6. Similarly, Lb. plantarum FB13 did not show co-aggregation with S. aureus $2 \mathrm{~S} 6$. 


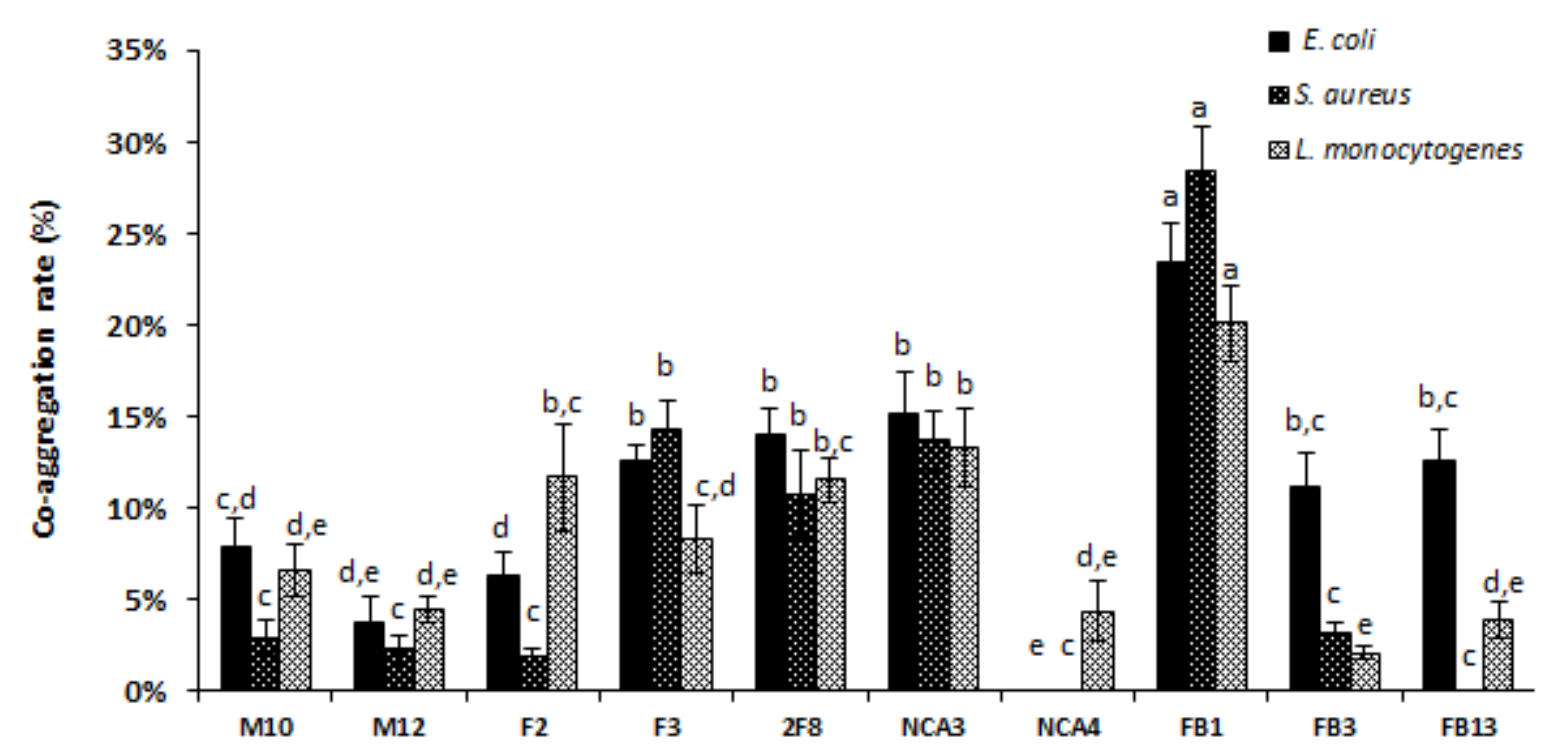

Figure 4. Co-aggregation ability of Lactobacillus strains with pathogens after $2 \mathrm{~h}$ of process. The rates are the means of three independent experiments. The error bars represent the standard deviations. Columns without a common letter are significantly different $(p<0.05)$ using Tukey's test.

\subsection{Anti-Adhesive Activity of Lactobacillus Strains towards Pathogens on Caco-2 Cells}

The adhesion rates to human epithelial Caco-2 cells of L. monocytogenes 162, S. aureus $2 S 6$ and E. coli ATCC 8739 were $8.40 \%, 7.25 \%$ and 7\%, respectively (Figure 5). However, when the adhesion experiment was performed, after incubating either pathogens with Lactobacillus strains, the adhesion levels decreased significantly $(p<0.05)$, as depicted in Figure 6. Regarding the competition method, when Lactobacillus strains were incubated simultaneously with pathogens, the adhesion rates decreased significantly $(p<0.05)$, ranging from $6.84 \%$ to $49.09 \%$ for E. coli ATCC $8739,9.05 \%$ to $45.74 \%$ for L. monocytogenes 162 , and $30.46 \%$ to $72.92 \%$ for S. aureus 2 S6 (Figure $6 \mathrm{~A}$ ). Based on the exclusion method, the adhesion appeared to further decrease. Indeed, when Lactobacillus strains were added to Caco-2 cells for 90 min before pathogen incorporation, we observed that rates were between $2.61 \%$ and $43.55 \%$ for E. coli ATCC $8739,5.13 \%$ and $40.89 \%$ for L. monocytogenes 162 and $24.32 \%$ and $65 \%$ for S. aureus 2 S6, as illustrated in Figure 6B. The lowest adhesion rate was reported following addition of Lb. plantarum F2 strain, with 2.61\%, 5.13\%, and 24.32\% for E. coli ATCC 8739, L. monocytogenes 162 and S. aureus 2S6, respectively. The presence of $L b$. paracasei FB1 exhibited a weak adhesion score, with only $3.97 \%$ in the presence of E. coli ATCC 8739, and this score reached 8.63\% in the presence of L. monocytogenes 162 and $36.05 \%$ for $S$. aureus $2 \mathrm{~S} 6$. 


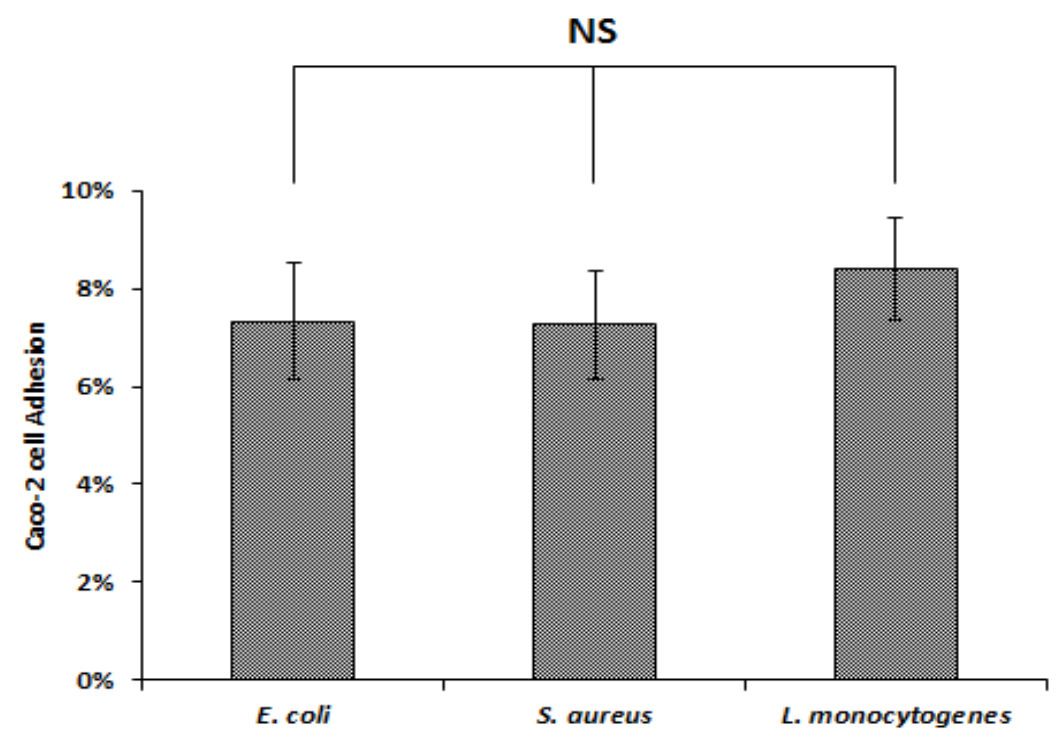

Figure 5. Adhesion percentage of the tested pathogens on Caco-2 cells. Each assay was conducted in triplicate. Means and standard errors are shown. NS, not significantly different $(p>0.05)$ using Tukey's test.
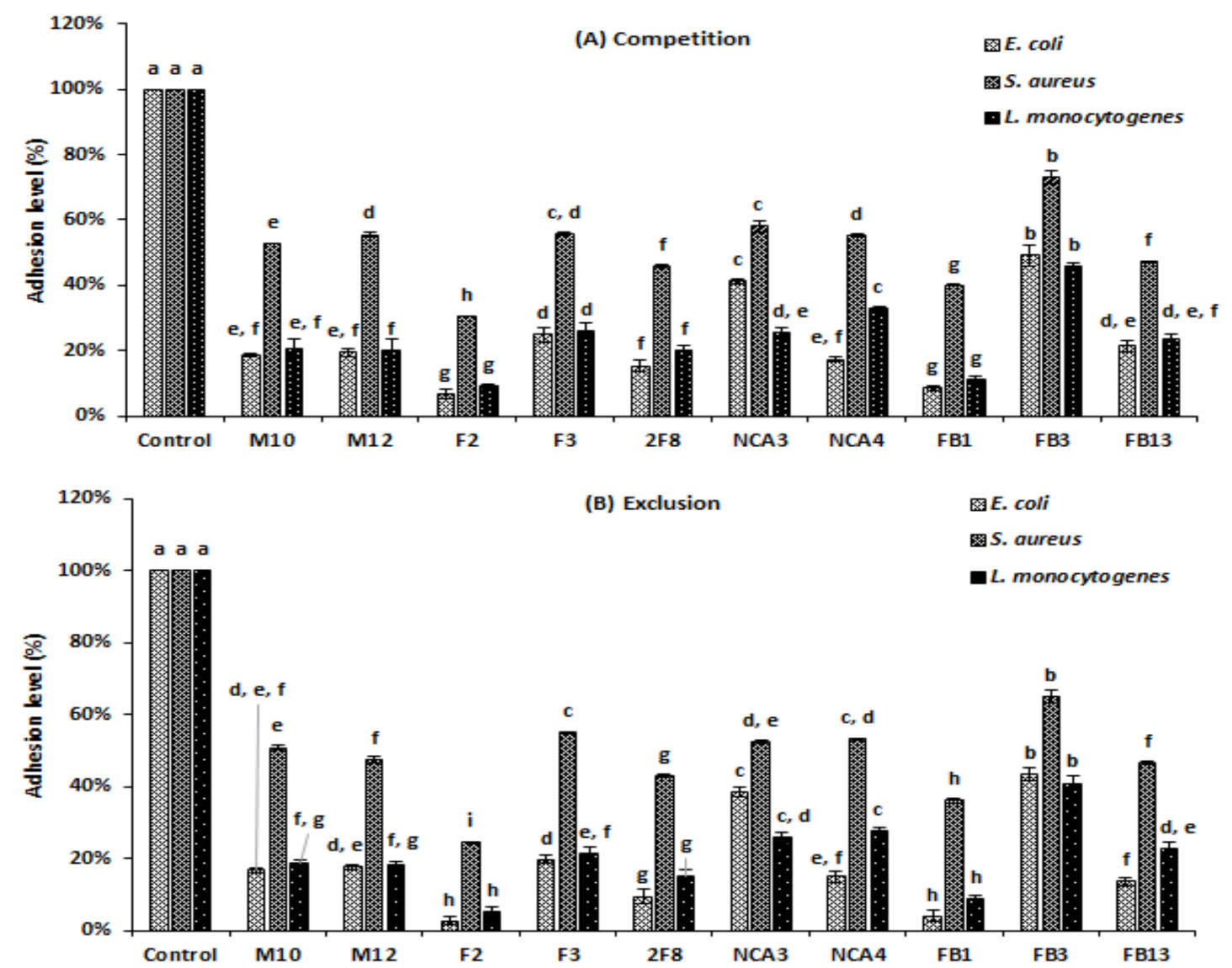

Figure 6. Adhesion rates of E. coli ATCC 8739, S. aureus 2S6 and L. monocytogenes 162 to Caco-2 cells in the presence of Lactobacillus strains. A: Competition (Lactobacillus strain with pathogen for $120 \mathrm{~min}$ ). B: Exclusion (pre-incubation of Lactobacillus strain for $90 \mathrm{~min}$, before adding pathogen for $120 \mathrm{~min}$ ). The rates are the means of three independent experiments. The columns without a common letter are different significantly $(p<0.05)$ using Tukey's test. 


\subsection{DPPH Free Radical Scavenging Activity}

In order to study the antioxidant potential of lactobacilli stains, the DPPH radical scavenging assay was used. Remarkably, the culture supernatants of ten Lactobacillus strains exhibited high DPPH scavenging activities, varying from $51.15 \% \pm 0.69 \%$ to $55.67 \% \pm 0.77 \%$ (Figure 7 ). We also studied the scavenging activities of the lactobacilli intact cells and intracellular extracts, as shown in Figure 7. The DPPH scavenging rates of intracellular extracts varied between $7.08 \% \pm 1.20 \%$ and $21.16 \% \pm 0.69 \%$, and were lower of those of intact cells $(19.21 \% \pm 1.28 \%$ and $40.18 \% \pm 1.49 \%)$. Interestingly, $L b$. paracasei FB1 strain exhibited the significantly $(p<0.05)$ higher scavenging DPPH rates either for supernatant, intact cells and intracellular extract with $55.67 \% \pm 0.38 \%, 40.18 \% \pm 1.49 \%$ and $21.16 \% \pm 0.69 \%$, respectively, followed by Lb. plantarum FB13 supernatant $(52.73 \% \pm 0.46 \%)$ and Lb. plantarum M10 intact cells $(35.71 \% \pm 1.68 \%)$ and intracellular extract $(16.01 \% \pm 0.13 \%)$.

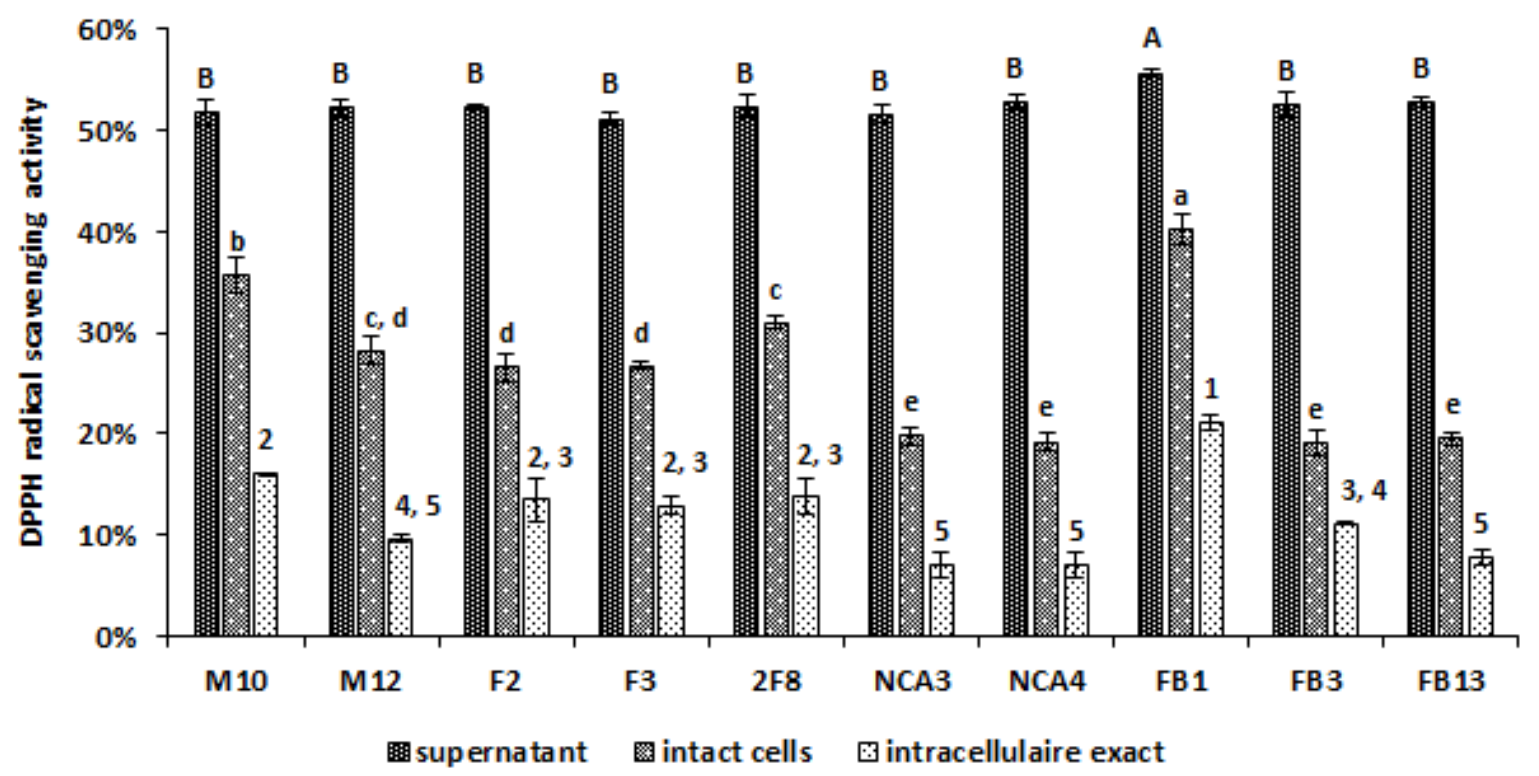

Figure 7. DPPH free radical scavenging activities by supernatants, intact cells and intracellular extract of Lactobacillus strains. Each rate was expressed as mean and standard errors are shown. Means within a column with different (number, lowercase and uppercase) letters are significantly different $(p<0.05)$ using one-way ANOVA with Tukey test for pairwise comparisons.

\subsection{Principal Component Analysis and Summary Hierarchical Classification of the Ten Studied Lactobacillus Strains}

The results of the PCA performed on the ten lactobacilli strains using 24 variables show that $81.14 \%$ of the total variation was distributed in four dimensions (Table S1), and the two most representative dimensions were Dim $1(36.48 \%)$ and Dim 2 (25.66\%) (Figure 8A). Thus, it was found that the five variables that most contributed to the construction of this PCA, and consequently to the projection of individuals (lactobacilli) in Figure 8B, were anti-E. coli activity (spot method), an antiadhesive effect against L. monocytogenes on Caco-2 cells, DPPH scavenging activities of CFS, acidification ( $\mathrm{pH}$ ) and EPS quantification (Figure 8A). Hierarchical principal component classification was performed based on the generated data in this study. Consequently, the lactobacilli were grouped into three main clusters (Figure 8C). The first cluster is composed of six strains, which are Lb. plantarum F2, 2F8, M10, M12, F3 and FB13. The second is represented by three strains that are Lb. plantarum NCA3, NCA4 and FB3. The variables (Table S2) allowing the classification of these nine strains into two groups are the acidification $(\mathrm{pH})$ and the antibacterial activity against $\mathrm{S}$. aureus using the well diffusion method. Indeed, the strains in the first group are significantly the most acidifying $(p<0.05)$ with the greatest antibacterial activity ( $p<0.05$ against $E$. coli, S. aureus and L. monocytogenes (well-diffusion method) and against E. coli (spot method). Meanwhile, the second group of these strains is less acidifying 
and exhibited a weaker antagonistic activity compared to Lb. plantarum strains contained in the first group. However, the third cluster is represented by one strain, namely Lb. paracasei FB1, which is significantly $(p<0.05)$ less acidifying, and with lower EPS production and antibacterial activities against $E$. coli and S. aureus (using spot method) compared to the other two clusters. This third cluster was significantly $(p<0.05)$ related to (i) high DPPH scavenging activities with CFS and intracellular extract, (ii) co-aggregation with E. coli, S. aureus and L. monocytogenes, and (iii) removing S. aureus and L. monocytogenes biofilms. Remarkably, the strains in the first and the third cluster had the most significant $(p<0.05)$ antiadhesive activities against $E$. coli and L. monocytogenes on Caco-2 cells.

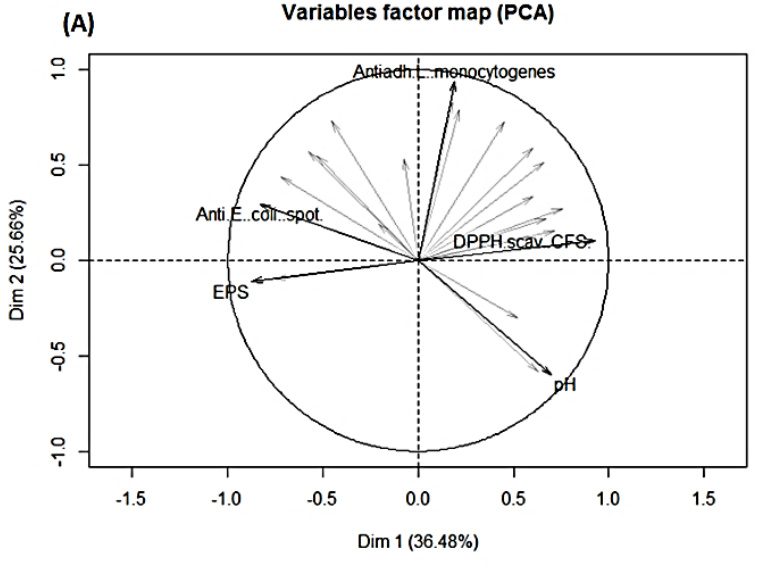

(C)

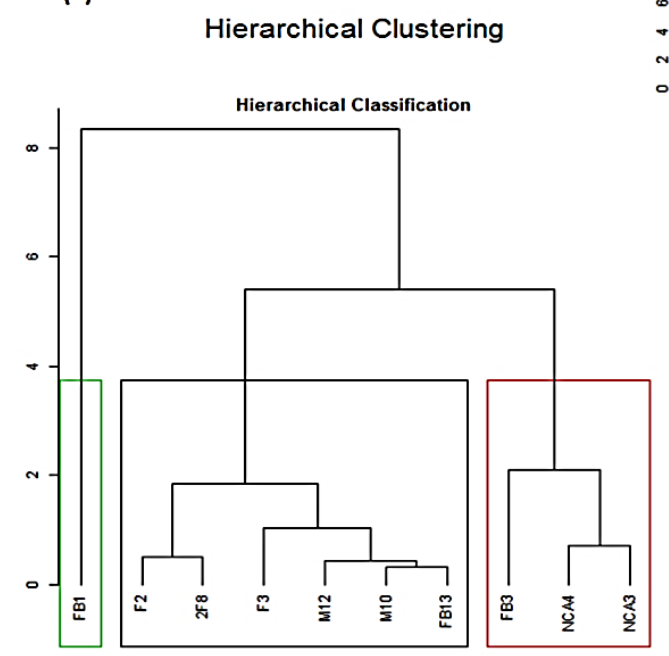

(B) Factor map

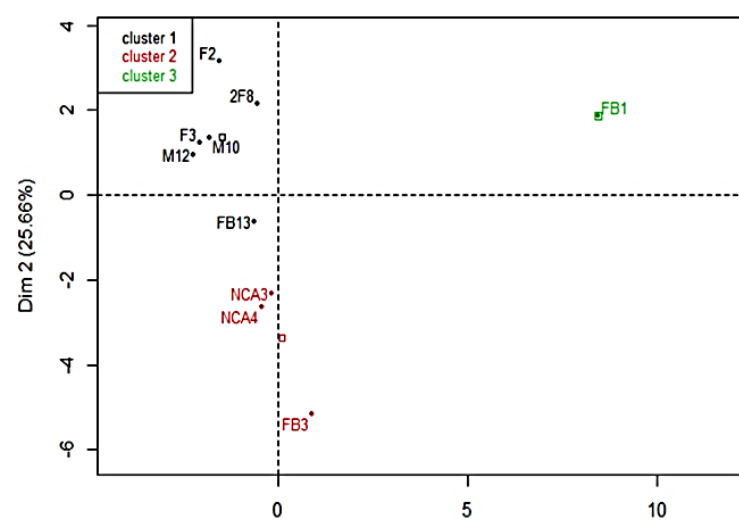

(D)

$\operatorname{Dim} 1(36.48 \%)$

Hierarchical clustering on the factor map
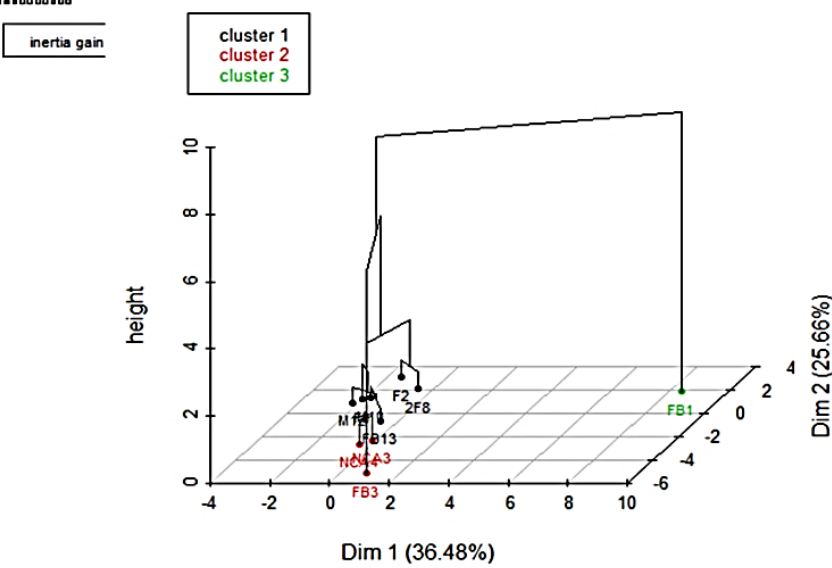

Figure 8. Principal component analysis (PCA) of Lactobacillus strains based on the antagonistic, antioxidant and production of both lactic acid and exopolysaccharides using FactoMineR. (A) Projection of the 24 variables into the two-dimensional space of Dim 1 and Dim 2; in bold are the variables that contributed most to the construction of the principal component analysis. (B) Projection of the ten Lactobacillus strains into the two-dimensional space, Dim 1 and Dim 2. (C) Hierarchical clustering of the Lactobacillus strains generated based on several tested proprieties. (D) Lactobacillus strains hierarchical grouping in a three-dimensional space.

\section{Discussion}

The antagonism and antioxidant effects of Lactobacillus strains are key elements in the selection of new strains predicted to be used as bio-preservative agents or qualified as probiotic candidates. Increasing studies have tended to use principal component analysis to select the promising strains [46,47], allowing researchers to group strains with similar characteristics within the same cluster. 
The inhibitory properties allocated to Lactobacillus strains are due to the production of different antimicrobial substances, such as organic acids that are usually used as food preservatives. Of note, acetic, citric and lactic acids were steadily reported and considered as the most studied organic acids. All of these organic acids are capable of controlling pathogens and stopping their proliferation. They can hamper their capability to form biofilms, or they can act on their quorum signaling pathways [48]. Here, ten novel Lactobacillus strains isolated from traditional Algerian fruits were assessed for their inhibitory properties against Gram-positive and Gram-negative pathogenic bacteria, which are representative of main foodborne pathogens. Consequently, the inhibitory properties of these Lactobacillus strains were shown to be associated mainly with the production of lactic acid, and exerted in a strain-dependent manner. Of note, these Lactobacillus strains of vegetal sources could produce up to $15 \mathrm{~g} / \mathrm{L}$ of lactic acid, except for Lb. plantarum FB3 and Lb. paracasei FB1 strains, which produced less than $10.75 \mathrm{~g} / \mathrm{L}$. These data fit with those usually reported in the literature. Production of organic acids has several advantages, and was shown, in different studies, to prevent contamination of food during the fermentation process [49-51]. Regarding their mode of action, organic acids decrease the intracellular $\mathrm{pH}$ of the targeted microorganisms, causing the inhibition of cell growth. More precisely, the addition of organic acids causes proton accumulation in the cytoplasm, which exceeds the buffering levels of the cells and their ability to pump out protons through the $\mathrm{H}^{+}$-ATPase transport system [13].

Moreover, all Lactobacillus strains considered in this study were able to produce large quantities of EPS, compared to other typical lactobacilli isolated from diverse sources $[52,53]$. The EPS structure can act as a capsule bound to the cell surface, allowing protection against toxic agents and stress conditions found during desiccation, or osmotic stress and acidity conditions [54,55].

To gain insight on these strains, we established here the role of non-neutralized CFSs obtained from $\mathrm{Lb}$. plantarum and $\mathrm{Lb}$. paracasei cultures in preventing the initial attachment of pathogenic bacteria such as E. coli ATCC 8739, S. aureus 2 S6 and L. monocytogenes 162 to a polystyrene surface. The addition of the non-neutralized CFS has a lasting effect on the biofilm formation by these foodborne pathogens. In direct line, Hossain et al. [56] reported that Lb. plantarum, Lb. curvatus and Lb. sakei isolated from kimchi impeded the biofilm formation by a clinical L. monocytogenes strain. Similarly, Mahdi et al. [43] showed the potential of a Lb. plantarum strain to prevent the biofilm formation by E. coli strains [52]. On the other hand, Cotar et al. [57] reported the role of organic acids, mainly that of lactic acid, produced by $L b$. paracasei subsp. paracasei strain, in the inhibition of the biofilm formation by Pseudomonas aeruginosa. All these examples delineate collectively the attributes of Lactobacillus strains in controlling the biofilm formation by pathogenic bacteria, through the production of organic acids. Nevertheless, these studies failed in showing the anti-adhesive properties of the Lactobacillus strains used.

Furthermore, we examined here the morphology and the cell structure of pathogenic bacteria following their treatments with the non-neutralized CFS using TEM. We then noticed clear changes in the global morphology, even in the cell ultra-structure of the aforementioned target bacteria, when they were treated with the CFS Lb. plantarum 2F8 strain that was characterized as one of the upmost strains for lactic acid production. Moreover, S. aureus 2S6 and E. coli ATCC 8739 were morphologically altered, whereas L. monocytogenes 162 exhibited a disruption of its cell membrane integrity. Similar alterations were previously observed for human pathogenic bacteria including staphylococci, enterotoxigenic enterobacteria, Candida albicans, Acinetobacter baumannii and L. monocytogenes treated with different Lactobacillus species like Limosilactobacillus fermentum, Lactobacillus jensenii, Lacticaseibacillus rhamnosus and Lacticaseibacillus paracasei species [58-60].

The Lactobacillus strains used here prevented the adhesion of E. coli ATCC 8739, S. aureus 2 S6 and L. monocytogenes 162 on eukaryotic Caco-2 cells, when used at an appropriate MOI ratio. In direct line with this, Yu et al. [61] reported the preventive effect of lactobacilli against enteric pathogenic bacteria using the same ratio of 10:1 (lactobacilli/pathogens). The anti-adhesive property of these Lactobacillus strains was dependent on many factors, including the conditions of incubation of Lactobacilli and pathogens during the competition and exclusion assays. Of note, the invasion of eukaryotic Caco- 2 
cells by L. monocytogenes, which is an intracellular pathogen, can be as well affected by these adherent Lactobacillus strains. The data gathered from the exclusion test are promising since they pointed out a clear protective effect against these pathogens, mainly by impeding their adhesion on the Caco-2 monolayer model, which strengthens our former report [34]. Of note, the abilities to hamper pathogens adhesion to the host tissues is as a key hurdle, and can therefore prevent their invasion process or limit some of their adverse effects, such as the destabilization of intercellular junctions [62].

In agreement with probiotic selection, Lactobacillus strains are known to prevent the adhesion of pathogenic bacteria to biotic surfaces by employing different mechanisms, other than the production of bioactive metabolites [63]. Among these mechanisms, the co-aggregation considered as a key strategy $[39,64]$ is of major interest. Here, the co-aggregation rate varied widely from one Lactobacillus strain to another. Thus Lb. plantarum NCA4 and FB13 strains lack this function, while Lb. paracasei FB1 displayed a co-aggregation rate of over $20 \%$ with all target bacteria tested. In good agreement with this, Lactobacillus strains were shown to control through the co-aggregation process the microenvironment around the pathogenic cells [64]. Beganović et al. [65], Ferrando et al. [66] reported that surface proteins of Lactobacillus strains were involved in both auto-aggregation and co-aggregation with pathogens. Thus, co-aggregation, as above-indicated, is a strategic function which can be involved in competitive and exclusion mechanisms, leading thereof to a reduction in pathogenic load during infections [67].

Among the interesting probiotics aspects, some Lactobacillus strains have been reported to have antioxidant properties by decreasing the level of oxidants such as reactive oxygen species (ROS) [68]. The DPPH assay is generally used in vitro to determine the scavenging activity, and is one of the most sensitive, common and reliable methods [69]. In this study, the lactobacilli antioxidant capacity was focused on intact cells, cell-free supernatants and intracellular extracts. The important DPPH scavenging rates using cell-free supernatants are consistent with those reported by Sharma et al. [43]. Otherwise, the DPPH scavenging activity of intact cells was greater than the rates recorded for the intracellular extracts, as reported in previous studies [70,71]. The intracellular extract can have a significant antioxidant postbiotic effect [72,73]. Many studies have revealed that antioxidant activity of Lactobacillus strains might be linked to their production of cell-surface compounds, e.g., lipoteichoic acid and EPS, and to antioxidant enzymes, such as superoxide dismutase, NADH-oxidase and $\mathrm{NADH}$-peroxide, and heterologous non-haem catalase [74,75].

\section{Conclusions}

Here, we characterized the antibacterial, anti-adhesive and antioxidant properties of ten Lactobacillus strains from vegetal sources, and confirmed their potential to produce lactic acid and EPS in a strain-dependent manner. In addition, we revealed, using TEM, accurate ultra-structure damages caused by lactic acid produced by these strains. These Lactobacillus strains exhibited capabilities to adhere on human Caco- 2 cells, as well as on inanimate surfaces; this mechanism stands as a hurdle to stop the proliferation of pathogens such as E. coli, S. aureus and L. monocytogenes. Collectively, the results from this study open up new possibilities for application of these new strains as potential probiotics or bioprotective cultures. For the probiotic application, they can be used, after further assessments, to protect human or animal GIT microbiota from malevolent pathogens and oxidative stress. For their application as bioprotective cultures, they can indeed be employed as a hurdle mean, mainly in processed foods from vegetal origin to replace chemicals and ascertain their safety. For both applications, further in vivo and in situ evidence is needed, and this will be our next focus.

Supplementary Materials: The following are available online at http://www.mdpi.com/2304-8158/9/8/985/s1. Table S1: Correlation, contribution and representation of the variables with the dimensions of the summary PCA based on factor loadings. Table S2: Description of each Lactobacillus cluster by quantitative variables.

Author Contributions: Conceptualization F.B. and D.D.; Data curation, N.B.; Formal analysis, N.B.; Funding acquisition, F.B. and D.D.; Investigation, N.B.; Methodology, N.B., Y.B. and R.L.; Project administration, F.B. and D.D.; Resources D.D. and F.B.; Software, N.B.; Validation, F.B., D.D., Y.B., R.L. Writing-original draft, N.B.; Writing-review \& editing, N.B., Y.B., R.L., F.B. and D.D. All authors have read and agreed to the published version of the manuscript. 
Funding: N.B. was supported by a short-term fellowship awarded by the Algerian and French governments through the PROFAS-B+ agreement. Research at Lille University was supported by ALIBIOTECH CPER/FEDER program from la Région des Hauts-de-France (2016-2021).

Conflicts of Interest: The authors declare no conflict of interest.

\section{References}

1. Jacob, C.; Mathiasen, L.; Powell, D. Designing effective messages for microbial food safety hazards. Food Control 2010, 21, 1-6. [CrossRef]

2. Mousavi Khaneghah, A.; Abhari, K.; Eş, I.; Soares, M.B.; Oliveira, R.B.A.; Hosseini, H.; Rezaei, M.; Balthazar, C.F.; Silva, R.; Cruz, A.G.; et al. Interactions between probiotics and pathogenic microorganisms in hosts and foods: A review. Trends Food Sci. Technol. 2020, 95, 205-218. [CrossRef]

3. Rawat, S. Food Spoilage: Microorganisms and their prevention. Asian J. Plant Sci. Res. 2015, 5.

4. Nyachuba, D.G. Foodborne illness: Is it on the rise? Nutr. Rev. 2010, 68, 257-269. [CrossRef] [PubMed]

5. Painter, J.A.; Hoekstra, R.M.; Ayers, T.; Tauxe, R.V.; Braden, C.R.; Angulo, F.J.; Griffin, P.M. Attribution of Foodborne Illnesses, Hospitalizations, and Deaths to Food Commodities by using Outbreak Data, United States, 1998-2008. Emerg. Infect. Dis. 2013, 19, 407-415. [CrossRef] [PubMed]

6. Xue, J.; Zhang, W. Understanding China's food safety problem: An analysis of 2387 incidents of acute foodborne illness. Food Control 2013, 30, 311-317. [CrossRef]

7. Fetsch, A.; Johler, S. Staphylococcus aureus as a Foodborne Pathogen. Curr. Clin. Microbiol. Rep. 2018, 5, 88-96. [CrossRef]

8. Kavitha, S.; Harikrishnan, A.; Jeevaratnam, K. Characterization and evaluation of antibacterial efficacy of a novel antibiotic-type compound from a probiotic strain Lactobacillus plantarum KJB23 against food-borne pathogens. LWT 2020, 118, 108759. [CrossRef]

9. Andersson, D.I.; Hughes, D. Antibiotic resistance and its cost: Is it possible to reverse resistance? Nat. Rev. Microbiol. 2010, 8, 260-271. [CrossRef]

10. Chammem, N.; Issaoui, M.; De Almeida, A.I.D.; Delgado, A.M. Food Crises and Food Safety Incidents in European Union, United States, and Maghreb Area: Current Risk Communication Strategies and New Approaches. J. AOAC Int. 2018, 101, 923-938. [CrossRef]

11. Ouarabi, L.; Chait, Y.A.; Seddik, H.A.; Drider, D.; Bendali, F. Newly Isolated Lactobacilli strains from Algerian Human Vaginal Microbiota: Lactobacillus fermentum Strains Relevant Probiotic's Candidates. Probiotics Antimicrob. Proteins 2019, 11, 43-54. [CrossRef] [PubMed]

12. Del Nobile, M.A.; Lucera, A.; Costa, C.; Conte, A. Food applications of natural antimicrobial compounds. Front. Microbiol. 2012, 3, 287. [CrossRef]

13. Corsetti, A.; Perpetuini, G.; Tofalo, R. 13-Biopreservation effects in fermented foods. In Advances in Fermented Foods and Beverages; Holzapfel, W., Ed.; Woodhead Publishing Series in Food Science, Technology and Nutrition; Woodhead Publishing: Sawston, UK, 2015; pp. 311-332, ISBN 978-1-78242-015-6.

14. Thakkar, P.N.; Patel, A.; Modi, H.A.; Prajapati, J.B. Hypocholesterolemic Effect of Potential Probiotic Lactobacillus fermentum Strains Isolated from Traditional Fermented Foods in Wistar Rats. Probiotics Antimicrob. Proteins 2019. [CrossRef]

15. Lin, X.; Xia, Y.; Yang, Y.; Wang, G.; Zhou, W.; Ai, L. Probiotic characteristics of Lactobacillus plantarum AR113 and its molecular mechanism of antioxidant. LWT 2020, 126, 109278. [CrossRef]

16. Vieco-Saiz, N.; Belguesmia, Y.; Raspoet, R.; Auclair, E.; Gancel, F.; Kempf, I.; Drider, D. Benefits and Inputs From Lactic Acid Bacteria and Their Bacteriocins as Alternatives to Antibiotic Growth Promoters During Food-Animal Production. Front. Microbiol. 2019, 10, 57. [CrossRef]

17. Bintsis, T. Lactic acid bacteria: Their applications in foods. J. Bacteriol. Mycol. 2018, 6, 89-94.

18. Chapman, C.M.C.; Gibson, G.R.; Rowland, I. Effects of single- and multi-strain probiotics on biofilm formation and in vitro adhesion to bladder cells by urinary tract pathogens. Anaerobe 2014, 27, 71-76. [CrossRef]

19. Cui, T.; Bai, F.; Sun, M.; Lv, X.; Li, X.; Zhang, D.; Du, H. Lactobacillus crustorum ZHG 2-1 as novel quorum-quenching bacteria reducing virulence factors and biofilms formation of Pseudomonas aeruginosa. LWT 2020, 117, 108696. [CrossRef] 
20. Tarrah, A.; Da Silva Duarte, V.; De Castilhos, J.; Pakroo, S.; Lemos Junior, W.J.F.; Luchese, R.H.; Fioravante Guerra, A.; Rossi, R.C.; Righetto Ziegler, D.; Corich, V.; et al. Probiotic potential and biofilm inhibitory activity of Lactobacillus casei group strains isolated from infant feces. J. Funct. Foods 2019, 54, 489-497. [CrossRef]

21. Jang, H.J.; Lee, N.-K.; Paik, H.-D. Probiotic characterization of Lactobacillus brevis KU15153 showing antimicrobial and antioxidant effect isolated from kimchi. Food Sci. Biotechnol. 2019, 28, 1521-1528. [CrossRef]

22. Coenye, T.; Kjellerup, B.; Stoodley, P.; Bjarnsholt, T. The future of biofilm research-Report on the '2019 Biofilm Bash'. Biofilm 2020, 2, 100012. [CrossRef]

23. Tan, Y.; Leonhard, M.; Moser, D.; Ma, S.; Schneider-Stickler, B. Inhibitory effect of probiotic lactobacilli supernatants on single and mixed non-albicans Candida species biofilm. Arch. Oral Biol. 2018, 85, 40-45. [CrossRef] [PubMed]

24. Campana, R.; Van Hemert, S.; Baffone, W. Strain-specific probiotic properties of lactic acid bacteria and their interference with human intestinal pathogens invasion. Gut Pathog. 2017, 9, 12. [CrossRef] [PubMed]

25. Davoren, M.J.; Liu, J.; Castellanos, J.; Rodríguez-Malavé, N.I.; Schiestl, R.H. A novel probiotic, Lactobacillus johnsonii 456, resists acid and can persist in the human gut beyond the initial ingestion period. Gut Microbes 2019, 10, 458-480. [CrossRef]

26. Kim, Y.; Oh, S.; Kim, S.H. Released exopolysaccharide (r-EPS) produced from probiotic bacteria reduce biofilm formation of enterohemorrhagic Escherichia coli O157:H7. Biochem. Biophys. Res. Commun. 2009, 379, 324-329. [CrossRef]

27. Reis, J.A.; Paula, A.T.; Casarotti, S.N.; Penna, A.L.B. Lactic Acid Bacteria Antimicrobial Compounds: Characteristics and Applications. Food Eng. Rev. 2012, 4, 124-140. [CrossRef]

28. Vitali, B.; Minervini, G.; Rizzello, C.G.; Spisni, E.; Maccaferri, S.; Brigidi, P.; Gobbetti, M.; Di Cagno, R. Novel probiotic candidates for humans isolated from raw fruits and vegetables. Food Microbiol. 2012, 31, 116-125. [CrossRef]

29. De Albuquerque, T.M.R.; Garcia, E.F.; De Oliveira Araújo, A.; Magnani, M.; Saarela, M.; De Souza, E.L. In Vitro Characterization of Lactobacillus Strains Isolated from Fruit Processing By-Products as Potential Probiotics. Probiotics Antimicrob. Proteins 2018, 10, 704-716. [CrossRef]

30. Sakandar, H.A.; Kubow, S.; Sadiq, F.A. Isolation and in-vitro probiotic characterization of fructophilic lactic acid bacteria from Chinese fruits and flowers. LWT 2019, 104, 70-75. [CrossRef]

31. Barache, N.; Ladjouzi, R.; Belguesmia, Y.; Bendali, F.; Drider, D. Abundance of Lactobacillus plantarum Strains with Beneficial Attributes in Blackberries (Rubus sp.), Fresh Figs (Ficus carica), and Prickly Pears (Opuntia ficus-indica) Grown and Harvested in Algeria. Probiotics Antimicrob. Proteins 2020. [CrossRef]

32. Al-Seraih, A.; Belguesmia, Y.; Baah, J.; Szunerits, S.; Boukherroub, R.; Drider, D. Enterocin B3A-B3B produced by LAB collected from infant faeces: Potential utilization in the food industry for Listeria monocytogenes biofilm management. Antonie Leeuwenhoek 2017, 110, 205-219. [CrossRef] [PubMed]

33. Bendali, F.; Durand, A.; Hébraud, M.; Sadoun, D. Lactobacillus paracasei subsp. paracasei: An Algerian isolate with antibacterial activity against enteric pathogens and probiotic fitness. J. Food Nutr. Res. Slovak Repub. 2011, 50, 139-149.

34. Ait Seddik, H.; Bendali, F.; Cudennec, B.; Drider, D. Anti-pathogenic and probiotic attributes of Lactobacillus salivarius and Lactobacillus plantarum strains isolated from feces of Algerian infants and adults. Res. Microbiol. 2017, 168, 244-254. [CrossRef]

35. Ait Ouali, F.; Al Kassaa, I.; Cudennec, B.; Abdallah, M.; Bendali, F.; Sadoun, D.; Chihib, N.-E.; Drider, D. Identification of lactobacilli with inhibitory effect on biofilm formation by pathogenic bacteria on stainless steel surfaces. Int. J. Food Microbiol. 2014, 191, 116-124. [CrossRef]

36. Stepanović, S.; Vuković, D.; Dakić, I.; Savić, B.; Švabić-Vlahović, M. A modified microtiter-plate test for quantification of staphylococcal biofilm formation. J. Microbiol. Methods 2000, 40, 175-179. [CrossRef]

37. Van Geel-Schutten, G.H.; Flesch, F.; Ten Brink, B.; Smith, M.R.; Dijkhuizen, L. Screening and characterization of Lactobacillus strains producing large amounts of exopolysaccharides. Appl. Microbiol. Biotechnol. 1998, 50, 697-703. [CrossRef]

38. Shokri, D.; Khorasgani, M.R.; Mohkam, M.; Fatemi, S.M.; Ghasemi, Y.; Taheri-Kafrani, A. The Inhibition Effect of Lactobacilli Against Growth and Biofilm Formation of Pseudomonas aeruginosa. Probiotics Antimicrob. Proteins 2018, 10, 34-42. [CrossRef] [PubMed] 
39. Kos, B.; Susković, J.; Vuković, S.; Simpraga, M.; Frece, J.; Matosić, S. Adhesion and aggregation ability of probiotic strain Lactobacillus acidophilus M92. J. Appl. Microbiol. 2003, 94, 981-987. [CrossRef]

40. Pinto, M.; Robineleon, S.; Appay, M.D.; Kedinger, M.; Triadou, N.; Dussaulx, E.; Lacroix, B.; Simonassmann, P.; Haffen, K.; Fogh, J.; et al. Enterocyte-like differentiation and polarization of the human-colon carcinoma cell-line Caco-2 in culture. Biol. Cell 1983, 47, 323-330.

41. Bendali, F.; Hébraud, M.; Sadoun, D. Anti-bacterial and anti-adherence activities of a probiotic strain of Lactobacillus paracasei subsp. paracasei against Listeria monocytogenes. Int. J. Appl. Microbiol. Biotechnol. Res. 2014, 2, 52-63.

42. Jayashree, S.; Karthikeyan, R.; Nithyalakshmi, S.; Ranjani, J.; Gunasekaran, P.; Rajendhran, J. Anti-adhesion Property of the Potential Probiotic Strain Lactobacillus fermentum 8711 Against Methicillin-Resistant Staphylococcus aureus (MRSA). Front. Microbiol. 2018, 9, 411. [CrossRef] [PubMed]

43. Sharma, K.; Mahajan, R.; Attri, S.; Goel, G. Selection of indigenous Lactobacillus paracasei CD4 and Lactobacillus gastricus BTM 7 as probiotic: Assessment of traits combined with principal component analysis. J. Appl. Microbiol. 2017, 122, 1310-1320. [CrossRef] [PubMed]

44. Ianniello, R.G.; Ricciardi, A.; Parente, E.; Tramutola, A.; Reale, A.; Zotta, T. Aeration and supplementation with heme and menaquinone affect survival to stresses and antioxidant capability of Lactobacillus casei strains. LWT 2015, 60, 817-824. [CrossRef]

45. Hnasko, R.M.; Lin, A.V.; Stanker, L.H.; Bala, K.; McGarvey, J.A. Prion Extraction Methods: Comparison of Bead Beating, Ultrasonic Disruption, and Repeated Freeze-Thaw Methodologies for the Recovery of Functional Renilla-Prion Fusion Protein from Bacteria. In Sample Preparation Techniques for Soil, Plant, and Animal Samples; Micic, M., Ed.; Springer Protocols Handbooks; Springer: New York, NY, USA, 2016; pp. 389-399. ISBN 978-1-4939-3185-9.

46. Mallappa, R.H.; Singh, D.K.; Rokana, N.; Pradhan, D.; Batish, V.K.; Grover, S. Screening and selection of probiotic Lactobacillus strains of Indian gut origin based on assessment of desired probiotic attributes combined with principal component and heatmap analysis. LWT 2019, 105, 272-281. [CrossRef]

47. Tang, H.; Qian, B.; Xia, B.; Zhuan, Y.; Yao, Y.; Gan, R.; Zhang, J. Screening of lactic acid bacteria isolated from fermented Cornus officinalis fruits for probiotic potential. J. Food Saf. 2018, 38, e12565. [CrossRef]

48. Amrutha, B.; Sundar, K.; Shetty, P.H. Effect of organic acids on biofilm formation and quorum signaling of pathogens from fresh fruits and vegetables. Microb. Pathog. 2017, 111, 156-162. [CrossRef]

49. Ait Seddik, H.; Bendali, F.; Gancel, F.; Fliss, I.; Spano, G.; Drider, D. Lactobacillus plantarum and Its Probiotic and Food Potentialities. Probiotics Antimicrob. Proteins 2017, 9, 111-122. [CrossRef]

50. Fu, W.; Mathews, A.P. Lactic acid production from lactose by Lactobacillus plantarum: Kinetic model and effects of pH, substrate, and oxygen. Biochem. Eng. J. 1999, 3, 163-170. [CrossRef]

51. Passos, F.V.; Fleming, H.P.; Ollis, D.F.; Felder, R.M.; McFeeters, R.F. Kinetics and Modeling of Lactic Acid Production by Lactobacillus plantarum. Appl. Environ. Microbiol. 1994, 60, 2627-2636. [CrossRef]

52. Mahdhi, A.; Leban, N.; Chakroun, I.; Chaouch, M.A.; Hafsa, J.; Fdhila, K.; Mahdouani, K.; Majdoub, H. Extracellular polysaccharide derived from potential probiotic strain with antioxidant and antibacterial activities as a prebiotic agent to control pathogenic bacterial biofilm formation. Microb. Pathog. 2017, 109, 214-220. [CrossRef]

53. Bengoa, A.A.; Llamas, M.G.; Iraporda, C.; Dueñas, M.T.; Abraham, A.G.; Garrote, G.L. Impact of growth temperature on exopolysaccharide production and probiotic properties of Lactobacillus paracasei strains isolated from kefir grains. Food Microbiol. 2018, 69, 212-218. [CrossRef] [PubMed]

54. Han, P.; Sun, Y.; Wu, X.; Yuan, Y.; Dai, Y.; Jia, S. Emulsifying, Flocculating, and Physicochemical Properties of Exopolysaccharide Produced by Cyanobacterium Nostoc flagelliforme. Appl. Biochem. Biotechnol. 2014, 172, 36-49. [CrossRef] [PubMed]

55. Vasanthakumari, D.S.; Harikumar, S.; Beena, D.J.; Pandey, A.; Nampoothiri, K.M. Physicochemical Characterization of an Exopolysaccharide Produced by a Newly Isolated Weissella cibaria. Appl. Biochem. Biotechnol. 2015, 176, 440-453. [CrossRef] [PubMed]

56. Hossain, M.I.; Mizan, M.F.R.; Ashrafudoulla, M.; Nahar, S.; Joo, H.-J.; Jahid, I.K.; Park, S.H.; Kim, K.-S.; Ha, S.-D. Inhibitory effects of probiotic potential lactic acid bacteria isolated from kimchi against Listeria monocytogenes biofilm on lettuce, stainless-steel surfaces, and MBEC ${ }^{\text {TM }}$ biofilm device. LWT 2020, 118, 108864. [CrossRef] 
57. Cotar, I.A.; Saviuc, C.; Andreea Nita, R.; Bezirtzoglou, E.; Lazar, V.; Carmen Chifiriuc, M. Anti-pathogenic Strategies for Fighting Pseudomonas aeruginosa Infections- probiotic Soluble Compounds as Inhibitors of Quorum Sensing Genes Expression. Curr. Org. Chem. 2013, 17, 155-161. [CrossRef]

58. Bendali, F.; Gaillard-Martinie, B.; Hebraud, M.; Sadoun, D. Kinetic of production and mode of action of the Lactobacillus paracasei subsp. paracasei anti-listerial bacteriocin, an Algerian isolate. LWT 2008, 41, 1784-1792. [CrossRef]

59. Rybalchenko, O.V.; Bondarenko, V.M.; Orlova, O.G.; Markov, A.G.; Amasheh, S. Inhibitory effects of Lactobacillus fermentum on microbial growth and biofilm formation. Arch. Microbiol. 2015, 197, 1027-1032. [CrossRef] [PubMed]

60. Sambanthamoorthy, K.; Feng, X.; Patel, R.; Patel, S.; Paranavitana, C. Antimicrobial and antibiofilm potential of biosurfactants isolated from lactobacilli against multi-drug-resistant pathogens. BMC Microbiol. 2014, 14, 197. [CrossRef] [PubMed]

61. Yu, Q.; Wang, Z.; Yang, Q. Ability of Lactobacillus to inhibit enteric pathogenic bacteria adhesion on Caco-2 cells. World J. Microbiol. Biotechnol. 2011, 27, 881-886. [CrossRef]

62. Lemichez, E.; Lecuit, M.; Nassif, X.; Bourdoulous, S. Breaking the wall: Targeting of the endothelium by pathogenic bacteria. Nat. Rev. Microbiol. 2010, 8, 93-104. [CrossRef]

63. Del Re, B.; Sgorbati, B.; Miglioli, M.; Palenzona, D. Adhesion, autoaggregation and hydrophobicity of 13 strains of Bifidobacterium longum. Lett. Appl. Microbiol. 2000, 31, 438-442. [CrossRef] [PubMed]

64. Merino, L.; Trejo, F.M.; De Antoni, G.; Golowczyc, M.A. Lactobacillus strains inhibit biofilm formation of Salmonella sp. isolates from poultry. Food Res. Int. 2019, 123, 258-265. [CrossRef] [PubMed]

65. Beganović, J.; Frece, J.; Kos, B.; Leboš Pavunc, A.; Habjanič, K.; Šušković, J. Functionality of the S-layer protein from the probiotic strain Lactobacillus helveticus M92. Antonie Leeuwenhoek 2011, 100, 43-53. [CrossRef] [PubMed]

66. Ferrando, V.; Quiberoni, A.; Reinheimer, J.; Suárez, V. Functional properties of Lactobacillus plantarum strains: A study in vitro of heat stress influence. Food Microbiol. 2016, 54, 154-161. [CrossRef]

67. Kaewnopparat, S.; Dangmanee, N.; Kaewnopparat, N.; Srichana, T.; Chulasiri, M.; Settharaksa, S. In vitro probiotic properties of Lactobacillus fermentum SK5 isolated from vagina of a healthy woman. Anaerobe 2013, 22, 6-13. [CrossRef]

68. Mu, G.; Li, H.; Tuo, Y.; Gao, Y.; Zhang, Y. Antioxidative effect of Lactobacillus plantarum Y44 on 2,2'-azobis(2-methylpropionamidine) dihydrochloride (ABAP)-damaged Caco-2 cells. J. Dairy Sci. 2019, 102, 6863-6875. [CrossRef]

69. Mishra, V.; Shah, C.; Mokashe, N.; Chavan, R.; Yadav, H.; Prajapati, J. Probiotics as Potential Antioxidants: A Systematic Review. J. Agric. Food Chem. 2015, 63, 3615-3626. [CrossRef]

70. Lin, M.-Y.; Chang, F.-J. Antioxidative Effect of Intestinal Bacteria Bifidobacterium longum ATCC 15708 and Lactobacillus acidophilus ATCC 4356. Dig. Dis. Sci. 2000, 45, 1617-1622. [CrossRef]

71. Chen, P.; Zhang, Q.; Dang, H.; Liu, X.; Tian, F.; Zhao, J.; Chen, Y.; Zhang, H.; Chen, W. Screening for potential new probiotic based on probiotic properties and $\alpha$-glucosidase inhibitory activity. Food Control 2014, 35, 65-72. [CrossRef]

72. Amaretti, A.; Di Nunzio, M.; Pompei, A.; Raimondi, S.; Rossi, M.; Bordoni, A. Antioxidant properties of potentially probiotic bacteria: In vitro and in vivo activities. Appl. Microbiol. Biotechnol. 2013, 97, 809-817. [CrossRef]

73. Aguilar-Toalá, J.E.; Garcia-Varela, R.; Garcia,H.S.; Mata-Haro, V.; González-Córdova, A.F.; Vallejo-Cordoba, B.; Hernández-Mendoza, A. Postbiotics: An evolving term within the functional foods field. Trends Food Sci. Technol. 2018, 75, 105-114. [CrossRef]

74. Li, S.; Zhao, Y.; Zhang, L.; Zhang, X.; Huang, L.; Li, D.; Niu, C.; Yang, Z.; Wang, Q. Antioxidant activity of Lactobacillus plantarum strains isolated from traditional Chinese fermented foods. Food Chem. 2012, 135, 1914-1919. [CrossRef] [PubMed]

75. Yang, S.-J.; Lee, J.-E.; Lim, S.-M.; Kim, Y.-J.; Lee, N.-K.; Paik, H.-D. Antioxidant and immune-enhancing effects of probiotic Lactobacillus plantarum 200655 isolated from kimchi. Food Sci. Biotechnol. 2019, 28, 491-499. [CrossRef] [PubMed]

(C) 2020 by the authors. Licensee MDPI, Basel, Switzerland. This article is an open access article distributed under the terms and conditions of the Creative Commons Attribution (CC BY) license (http://creativecommons.org/licenses/by/4.0/). 